Article

\title{
Lipid Isolation Process and Study on Some Molecular Species of Polar Lipid Isolated from Seed of Madhuca ellitica
}

\author{
Doan Lan Phuong ${ }^{1,2}$, Tran Quoc Toan ${ }^{1,2}{ }^{4}$, Ly P. T. Dang ${ }^{1}$, Andrey B. Imbs ${ }^{3}$, \\ Pham Quoc Long ${ }^{1,2, *}$, Tran Dinh Thang ${ }^{4}$, Bertrand Matthaeus ${ }^{5}{ }^{-0}$, Long Giang Bach ${ }^{6,7}$ and \\ Le Minh Bui ${ }^{6,7, *(D)}$ \\ 1 Institute of Natural Products Chemistry, Vietnam Academy of Science and Technology (VAST), \\ 18 Hoang Quoc Viet road, Caugiay district, Hanoi 10000, Vietnam; doanlanphuong75@gmail.com (D.L.P.); \\ tranquoctoan2010@gmail.com (T.Q.T.); phuongly1412@gmail.com (L.P.T.D.) \\ 2 Graduate University of Science and Technology, Vietnam Academy of Science and Technology (VAST), \\ 18 Hoang Quoc Viet road, Caugiay district, Hanoi 10000, Vietnam \\ 3 A.V. Zhirmunsky Institute of Marine Biology, Far-Eastern Branch of the Russian Academy of Sciences, \\ Vladivostok 690041, Russia; andrey_imbs@hotmail.com \\ 4 School of Chemistry, Biology and Environment, Vinh University, Vinh City 46000, Vietnam; \\ thangtd@vinhuni.edu.vn \\ 5 Working Group of Lipid Research, Department of Safety and Quality of Cereals Max, Federal Research \\ Institute for Nutrition and Food, Rubner-Institut, Schutzenberg 12, DE-32756 Detmold, Germany; \\ bertrand.matthaeus@mri.bund.de \\ 6 NTT Hi-Tech Institute, Nguyen Tat Thanh University, Ho Chi Minh City 70000, Vietnam; blgiang@ntt.edu.vn \\ 7 Center of Excellence for Biochemistry and Natural Products, Nguyen Tat Thanh University, \\ Ho Chi Minh City 70000, Vietnam \\ * Correspondence: mar.biochem@fpt.vn (P.Q.L.); blminh@ntt.edu.vn (L.M.B.)
}

Received: 18 May 2019; Accepted: 10 June 2019; Published: 17 June 2019

\begin{abstract}
This study attempted the lipid extraction process from the seeds of Madhuca ellitica, a lipid-rich plant, and conducted a lipidomic analysis on molecular species of the obtained product. Total lipids of the crude seeds were found to contain $11.2 \%$ of polar lipids. The major fatty acids (FAs) of the polar lipids were palmitic (16:0), stearic (18:0), oleic (18:1n-9), and linoleic $(18: 2 n-6)$ acids, which amounted to $28.5,12.5,44.8$, and $13.2 \%$ of total FAs, respectively. The content and chemical structures of individual molecular species of phosphatidylglycerol (PG), phosphatidylethanolamine (PE), phosphatidylcholine (PC), phosphatidylinositol (PI), phosphatidic acid (PA), and sulfoquinovosyldiacylglycerol (SQDG) were determined by HPLC with a tandem high-resolution mass spectrometry (HRMS). The major molecular species were 18:1/18:2 PE, 16:0/18:1 PC, 18:1/18:2 PC, 16:0/18:2 PG, 16:0/18:1 PG, 16:1/18:1 PI, 16:0/18:1 PI, 18:0/18:2 PI, 16:0/18:1 PA, 18:1/18:2 PA, 16:0/18:1 SQDG, and 18:0/18:1 SQDG. The application of a tandem HRMS allows us to determine the content of each isomer in pairs of the monoisotopic molecular species, for example, 18:0/18:2 and 18:1/18:1. The evaluation of the seed polar lipid profile will be helpful for developing the potential of this tree for nutritive and industrial uses.
\end{abstract}

Keywords: Madhuca ellitica; lipid molecular species; phospholipids; sulfoquinovosyldiacylglycerol; seeds; tandem high-resolution mass spectrometry

\section{Introduction}

Buttercup tree or mahua, Madhuca elliptica (Pierre ex Dubard) H.J.Lam, Madhuca longifolia (Koenig) J.F. Macb (Synonyms, Madhuca indica Gmelin, Madhuca latifolia Macb., Bassia latifolia Roxb.; 
Family, Sapotaceae) is a commercially important tree cultivated throughout the subtropical region of the Indo-Pak subcontinent and regarded highly for its flowers, fruits, timber, and seeds [1-3]. Previous reports have pointed out a myriad of valuable compounds, especially compounds of low molecular-weight including saponins, carbohydrates, triterpenoids, steroids, flavonoids, and glycosides, have been isolated from Madhuca [4-7]. Among these compounds, carotinoids, existing dominantly in the seeds of Madhuca, figure in certain medicinal applications for treatments of skin disease, rheumatism, headache, piles, and use as a laxative [8-10]. The Madhuca seed is also rich in fat (up to $58 \%$ ) [11,12], suggesting potential use of the seed in the manufacture of laundry soaps, lubricants and biodiesel $[13,14]$.

The base of the oil seeds of the plant is constituted of triacylglycerols (TG), which are neutral lipids. Also, natural seed fats contain a number of polar lipids, which are usually separated and lost during oil manufacturing. Among polar lipids, phospholipids hold great importance due to their nutritional value and bioactivities [15]. Each phospholipid class is a complex mixture of individual compounds, termed as "molecular species". Structures of phospholipids consists of the same polar group but different acyl chains of their molecules, which defines their nutritional value and bioactivities of phospholipid molecular species. Therefore, unambiguous identification of molecular species profile of the oilseed, through a lipidomic approach, may introduce possible application in the cosmetic, nutraceutical, and pharmaceutical industries [16,17]. Even though plant lipids and TG molecular species have been studied extensively in terms of compositional structure [18-20], information on the molecular species composition of phospholipids is scanty. For M. elliptica, previous studies have revealed its TG molecular species profile in seed fat and its solid and liquid fractions [21]. In addition, fatty acid (FA) composition of polar lipids and individual phospholipid class content of mahua butter from M. elliptica have been described [10]. The present work aimed to identify the chemical structure and quantitative composition of phospholipid molecular species from the M. elliptica seeds. The molecular species of sulfoquinovosyldiacylglycerols (SQDG), which contain a charged chemical group like phospholipid molecules, were also investigated. High performance liquid chromatography (HPLC), in tandem with high -resolution mass spectrometry (HRMS), was used as a lipidomic method [22]. Some important papers concerning molecular species of polar lipids in marine species, such as corals and red (hot) algae, have been recently published. For example, a previous study that investigated the distribution of tetracosapolyenoic acids (TPA) in molecular species of different phospholipid (PL) classes in the soft corals Sinularia macropodia and Capnella sp. from shallow waters of Vietnam showed some interesting results [23]. To be specific, Phosphatidylethanolamine (PE), phosphatidylcholine (PC), phosphatidylserine (PS), and phosphatidylinositol (PI) were found to be major PL classes of S. macropodia and Capnella sp. and more than 32 molecular species of these four PL classes were determined by high-resolution tandem mass spectrometry. The major molecular species of PL in both coral species were 18:1e/20:4 PE, 18:0e/20:4 PC, 18:0e/24:5 PS, and 18:0/24:5 PI. In two model red algae, Polysiphonia sp. and Porphyridium sp., forms of monogalactosyldiacylglycerol (MGDG) and digalactosyldiacylglycerol (DGDG), the two most commonly found galactolipids in chloroplast membranes, were determined via positive-ion electrospray ionization/mass spectrometry (ESI/MS) and ESI/MS/MS [24]. In the study of Honda et al. (2019) the characteristics of glycerolipids, which are the substrates of eicosanoids production of $A$. chilensis, were investigated and compared to the reported values of $A$. vermiculophyllum. The results showed that monogalactosyldiacylglycerol (MGDG), digalactosyldiacylglycerol (DGDG), sulfoquinovosyldiacylglycerol (SQDG), and phosphatidylcholine (PC) were the major lipid classes in A. chilensis and accounted for $44.4 \%$ of the total lipid extract [25].

\section{Materials and Methods}

\subsection{Materials}

Ripe fruits of M. ellitica (1000 g) were collected from a plantation in Binh Duong province of Vietnam in February 2016 and were botanically identified by Dr. Nguyen Quoc Binh, Vietnam National 
Museum of Nature-Vietnam Academy of Science and Technology. Seeds were cleaned, dried in cabinet dryer at $50{ }^{\circ} \mathrm{C}$ for $12 \mathrm{~h}$, and stored at $4{ }^{\circ} \mathrm{C}$ after collection. Water content (\%) in the M. ellitica seed was $10.27 \%$. To prepare the sample for analysis, $100 \mathrm{~g}$ of sample seeds were finely ground using an electric grinder (KIKA Labortechnik M20), after which they were immediately subjected to lipid extraction. Neutral lipid standards, phospholipid standards (phosphatidylglycerol (PG), phosphatidylethanolamine (PE), phosphatidylcholine (PC), phosphatidylinositol (PI), phosphatidic acid (PA)), and sulfoquinovosyldiacylglycerol (SQDG) were purchased from Sigma-Aldrich Co. (St. Louis, MO, USA).

\subsection{Extraction of Total Lipids (TL)}

M. ellitica powder was then extracted for TL following a previously described method of Folch et al. (1957) [26] in which a Soxhlet extractor in combination with a solvent mixture of $\mathrm{CHCl}_{3} / \mathrm{MeOH}(2: 1, \mathrm{v} / \mathrm{v})$ and aqueous solution of sodium chloride $(0.75 \%)$ were used. After being separated overnight at $4{ }^{\circ} \mathrm{C}$, the $\mathrm{CHCl}_{3}$ layer was recovered and dehydrated with sodium sulfate. The extract was filtered and subjected to a rotary evaporator at $40^{\circ} \mathrm{C}$, and TL obtained were dissolved in $\mathrm{CHCl}_{3}$ and stored at $-20^{\circ} \mathrm{C}$. The content of TL was determined gravimetrically.

\subsection{Lipid Fractionation}

A column incorporated with 100 g of silica gel 60 (70-230 mesh, Sigma-Aldrich Co., St. Louis, MO, USA) was loaded with TL (3.4 g). Neutral lipids, glycolipids, and phospholipids were eluted with $\mathrm{CHCl}_{3}(450 \mathrm{~mL})$, acetone $(230 \mathrm{~mL}), \mathrm{MeOH}(60 \mathrm{~mL})$, and $\mathrm{MeOH} /$ water $(200 \mathrm{~mL}, 95: 5, \mathrm{v} / \mathrm{v})$. The $\mathrm{MeOH}$-contained fractions were combined, taken to dryness, and polar lipids obtained were dissolved in $\mathrm{CHCl}_{3}$ and stored at $-20^{\circ} \mathrm{C}$.

\subsection{Analysis of Lipid Class Compositions}

One-dimensional thin layer chromatography (TLC) using precoated silica gel plates $(6 \mathrm{~cm} \times$ $6 \mathrm{~cm}$ ) Sorbfil PTLC-AF-V (Sorbfil, Krasnodar, Russia) was employed to analyze TL composition. The development of plates commenced with $n$-hexan/ $\mathrm{Et}_{2} \mathrm{O} / \mathrm{AcOH}(70: 20: 1, \mathrm{v} / \mathrm{v} / \mathrm{v})$ to their full length, followed with $\mathrm{CHCl}_{3} / \mathrm{MeOH} / \mathrm{C}_{6} \mathrm{H}_{6} / \mathrm{NH}_{4} \mathrm{OH}$ (65:30:5:10, v/v/v) to $25 \%$ length. Following that, plates were subjected to a stream of air for drying, sprayed with $10 \% \mathrm{H}_{2} \mathrm{SO}_{4}$ in $\mathrm{MeOH}$ and heated at $240{ }^{\circ} \mathrm{C}$ for $10 \mathrm{~min}$. An image scanner (Epson Perfection 2400 PHOTO) operating in grayscale mode was used to record the chromatograms. An image analysis software (Sorbfil TLC Videodensitometer, Krasnodar, Russia) was used to determine percentages of lipid contents based on band intensity. Peak areas and lipid class percentages were calculated according to Hamoutene (2008) [27]. In the first and second direction of separation of polar lipids using two-dimensional silica gel TLC, $\mathrm{CHCl}_{3} / \mathrm{MeOH} / \mathrm{C}_{6} \mathrm{H}_{6} / 28 \%$ $\mathrm{NH}_{4} \mathrm{OH}$ (65:30:10:6, v/v/v) and $\mathrm{CHCl}_{3} / \mathrm{MeOH} / \mathrm{AcOH} / \mathrm{CH}_{3} \mathrm{COCH}_{3} / \mathrm{C}_{6} \mathrm{H}_{6} / \mathrm{H}_{2} \mathrm{O}$ (70:30:4:5:10:1, v/v/v) were used, respectively. Identification of phospholipids on TLC plates was made using aforementioned authentic standards and the specific spray reagents [28]. The phospholipid content was evaluated with spectrophotometry following the digestion with perchloric acid [29].

\subsection{Analysis of Lipid Class Compositions}

To obtain fatty acid methyl esters (FAMEs), the lipids, contained in a screw cap vial, were treated with $2 \% \mathrm{H}_{2} \mathrm{SO}_{4}$ in $\mathrm{MeOH}$ for $2 \mathrm{~h}$ at $80{ }^{\circ} \mathrm{C}$ under Ar. The purification was performed by TLC development in benzene. The preparation of 4,4-Dimethyloxazoline (DMOX) derivatives of FAs from FAMEs follows the study of Svetashev (2011) [30].

FAMEs were analyzed by gas chromatography (GC) employed on a Shimadzu GC-2010 chromatograph (Kyoto, Japan) at $210{ }^{\circ} \mathrm{C}$. GC was performed in tandem with a flame ionization detector on a SUPELCOWAX 10 (Supelco, Bellefonte, PA, USA) capillary column $(30 \mathrm{~m} \times 0.25 \mathrm{~mm} \times$ $0.25 \mu \mathrm{m})$. Temperatures of both injector and detector were maintained at $240{ }^{\circ} \mathrm{C}$. Carrier gas was He at 
$30 \mathrm{~cm} / \mathrm{s}$. The identification of FAMEs was made by comparison with authentic standards (Supelco 37 Component FAME Mix; Supelco, Bellefonte, PA, USA) and a table of equivalent chain-lengths [31].

To identify structural composition of FAs, corresponding methyl esters and DMOX derivatives were analyzed by gas chromatography mass spectrometry (GC-MS) on a Shimadzu GCMS-2010 instrument (Kyoto, Japan) (electron impact at $70 \mathrm{eV}$ ) with a MDN-5s (Supelco, Bellefonte, PA, USA) capillary column $(30 \mathrm{~m} \times 0.25 \mathrm{~mm}$ ID). Carrier gas was He at $30 \mathrm{~cm} / \mathrm{s}$. The temperature parameter for analysis of FAMEs started at $160^{\circ} \mathrm{C}$, followed by an increase of $2{ }^{\circ} \mathrm{C} / \mathrm{min}$ to $240{ }^{\circ} \mathrm{C}$ that was held for $20 \mathrm{~min}$. Temperatures for both injector and detector temperatures were maintained at $250^{\circ} \mathrm{C}$. For analysis of GC-MS of DMOX derivatives, the temperature started at $210^{\circ} \mathrm{C}$, increased by $3{ }^{\circ} \mathrm{C} / \mathrm{min}$ to $270{ }^{\circ} \mathrm{C}$ that was held for $40 \mathrm{~min}$. The injector and detector temperatures were $250^{\circ} \mathrm{C}$ for this analysis. The mass spectra of FAMEs were compared with the Mass Spectral Library: WILEY275.L and NIST 98 [32].

\subsection{Analysis of Molecular Species of Polar Lipids}

Determination of chemical structures and molecular species of PL was performed by high performance liquid chromatography, in conjunction with high-resolution mass spectrometry (HPLC-HRMS). In the HPLC separation of the polar lipids, content of $\mathrm{Et}_{3} \mathrm{~N} / \mathrm{AcOH}(0.08: 1, \mathrm{v} / \mathrm{v})$ was fixed in the solvent system [33]. This permits an efficient electrospray ionization (ESI) and stabilizes ion signal by the simultaneous registration of positive and negative ions. A Shimadzu Prominence liquid chromatograph (Kyoto, Japan) was used to perform the HPLC-HRMS analysis of polar lipids. The instrument was equipped with two LC-20AD pump units, a high pressure gradient forming module, CTO-20A column oven, SIL-20A auto sampler, CBM-20A communications bus module, DGU-20A3 degasser, and a Shim-Pack diol column $(50 \mathrm{~mm} \times 4.6 \mathrm{~mm}$ ID, $5 \mu \mathrm{m}$ particle size) (Shimadzu, Kyoto, Japan). Two solvent mixtures, A and B, formed the binary solvent gradient for HPLC separation. The mixture A consisted of $n$-hexane/2-propanol/ $\mathrm{AcOH} / \mathrm{Et}_{3} \mathrm{~N}(82: 17: 1: 0.08, \mathrm{v} / \mathrm{v} / \mathrm{v} / \mathrm{v})$ and mixture $\mathrm{B}$ consisted of 2-propanol/ $\mathrm{H}_{2} \mathrm{O} / \mathrm{AcOH} \mathrm{Et}_{3} \mathrm{~N}(85: 14: 1: 0.08, \mathrm{v} / \mathrm{v} / \mathrm{v} / \mathrm{v})$. The acceleration of gradient started at $5 \%$ of mixture $\mathrm{B}$ and reached $80 \%$ throughout the course of $25 \mathrm{~min}$. After $1 \mathrm{~min}$, the composition changed to $5 \%$ of mixture B over $10 \mathrm{~min}$ and maintained at $5 \%$ for another $4 \mathrm{~min}$ (the total run time was $40 \mathrm{~min}$ ). The flow rate was $0.2 \mathrm{~mL} / \mathrm{min}$. Determination of lipids was performed by a high resolution tandem ion trap time of flight mass spectrometry with a Shimadzu LCMS-IT-TOF instrument (Kyoto, Japan). The instrument operates at both positive and negative ion mode during each analysis under ESI conditions. Temperature for ion source was set to $200{ }^{\circ} \mathrm{C}$. The range of detection was m/z 100-1200. Negative and positive modes had their potential set at-3.5 and $4.5 \mathrm{kV}$, respectively. The drying gas $\left(\mathrm{N}_{2}\right)$ pressure was $200 \mathrm{kPa}$. The nebulizer gas $\left(\mathrm{N}_{2}\right)$ flow was $1.5 \mathrm{~L} / \mathrm{min}$. For identification of lipids, authentic standards were compared with the samples, which was performed using Shimadzu LCMS Solution control and processing software (v.3.60.361). Molecular species of each phospholipid class were determined by HRMS fragmentation pathways in comparison with standards [30]. Individual molecular species within each polar lipid class were quantified with respect to the peak areas for the individual extracted ion chromatograms [34].

\section{Results}

\subsection{Total Lipid Composition}

Total lipids (TL) constituted $34.0 \pm 0.2 \%$ of the seed. The composition of TL is presented in Table 1 and Figure 1. The level of triacylglycerols (TG) was highest ( $63.2 \%$ of TL), followed by waxes (WX, $9.28 \%$ of TL), free fatty acids (FFA, $6.14 \%$ of TL), and diacylglycerols (DG, $5.17 \%$ of TL). Polar lipids constituted $11.2 \%$ of TL and contained glycolipids (GL, $6.78 \%$ of TL) and phospholipids (PL, $4.45 \%$ of TL). Five major classes were found in the total PL including Phosphatidylcholine (PC), phosphatidylethanolamine (PE), phosphatidylinositol (PI), phosphatidylglycerol (PG), and phosphatidic acid (PA). These five classes amounted to $13.2,13.1,7.7,4.9$, and $2.9 \%$ of total PL, respectively. 
Table 1. Lipid class composition (\% of total lipid) and Phospholipid (PL) class (\% of total Phospholipids) obtained from Madhuca ellitica seeds.

\begin{tabular}{cccc}
\hline Lipid Class & Content $\mathbf{( \% )}$ & Phospholipid (PL) Class & Content (\%) \\
\hline Waxes & $5.28 \pm 0.1$ & PC & $30.7 \pm 0.4$ \\
Triacylglycerols & $63.2 \pm 1.5$ & PE & $29.6 \pm 0.3$ \\
Diacylglycerols & $5.17 \pm 0.9$ & PI & $17.2 \pm 0.1$ \\
Free fatty acids & $6.14 \pm 0.6$ & PG & $10.9 \pm 0.2$ \\
Glycolipids & $5.78 \pm 0.2$ & PA & $6.8 \pm 0.1$ \\
Phospholipids & $14.43 \pm 1.3$ & LPE & $4.8 \pm 0.1$ \\
\hline
\end{tabular}

Results are given as the average of triplicate determinations \pm standard deviation. PC: phosphatidylcholine; PE: phosphatidylethanolamine; PI: phosphatidylinositol; PG: phosphatidylglycerol; PA: phosphatidic acid; LPE: Lyso-PE.

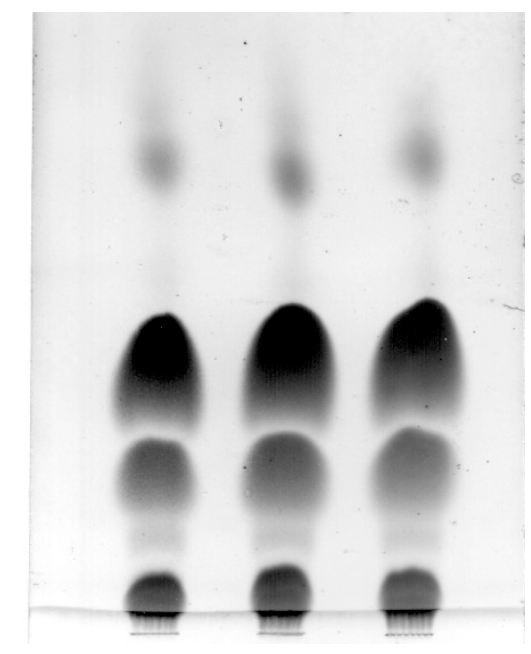

Figure 1. Lipid classes of the M. ellitica on Sorbfil thin layer chromatography (TLC).

\subsection{Fatty Acid Composition of Total Lipids and Lipid Fractions}

The FA composition of TL and their fractions, obtained from of M. elliptica seeds, is presented in Table 2. Oleic (18:1n-9), palmitic (16:0), stearic (18:0), and linoleic (18:2n-6) acids were the major FAs, collectively composing more than $98 \%$ of the total identified FAs. In general, the prevalence of unsaturated FAs is the major characteristic of the FA composition of TL. Oleic acid was the main FA (49.5\%) followed by palmitic acid. The FA profiles of TL, neutral, and polar lipid fractions were similar. In addition, low levels of myristic (14:0), $\alpha$-linolenic (18:3n-3), and arachidic (20:0) acids were detected.

Table 2. Fatty acid composition (\% of total fatty acids) of total, neutral, and polar lipids obtained from Madhuca ellitica seeds.

\begin{tabular}{cccc}
\hline Fatty Acids & Total Lipids & Neutral Lipids & Polar Lipids \\
\hline $14: 0$ & $0.1 \pm 0.1$ & $0.2 \pm 0.1$ & $0.1 \pm 0.1$ \\
$16: 0$ & $24.4 \pm 1.2$ & $25.7 \pm 1.4$ & $28.5 \pm 1.7$ \\
$16: 1 \mathrm{n}-7$ & $0.1 \pm 0.1$ & $0.1 \pm 0.1$ & nd \\
$18: 0$ & $11.5 \pm 0.5$ & $13.5 \pm 2.3$ & $12.5 \pm 1.8$ \\
$18: 1 \mathrm{n}-9$ & $49.5 \pm 3.5$ & $46.1 \pm 2.8$ & $44.8 \pm 2.9$ \\
$18: 2 \mathrm{n}-6$ & $13.6 \pm 1.1$ & $13.6 \pm 0.9$ & $13.2 \pm 1.3$ \\
$18: 3 \mathrm{n}-3$ & $0.1 \pm 0.1$ & $0.2 \pm 0.1$ & $0.3 \pm 0.1$ \\
$20: 0$ & $0.4 \pm 0.2$ & $0.4 \pm 0.2$ & $0.3 \pm 0.1$ \\
¿ SFA & $36.4 \pm 0.4$ & $39.8 \pm 0.6$ & $41.4 \pm 0.5$ \\
$\Sigma$ UFA & $63.3 \pm 1.7$ & $60.0 \pm 1.1$ & $58.3 \pm 1.3$ \\
SFA/UFA & 0.58 & 0.66 & 0.71 \\
\hline
\end{tabular}

nd: not detected or under $0.1 \%$ of fatty acid composition in each type phospholipid; SFA: saturated fatty acids. UFA: unsaturated fatty acids. 


\subsection{Chemical Structure of Molecular Species of Polar Lipids}

The phospholipid classes of M. ellitica seeds were separated by HPLC-HRMS. The retention times of different molecular species of PE, PG, PA, PC, and PI were 5.90-6.87 min, 8.54-8.89 min, 9.18-9.37 $\mathrm{min}, 9.84-10.35 \mathrm{~min}$, and 12.31-13.28 min, respectively. Among molecular species, four species including PE, PG, PA, and PI were revealed to be detectable at the $\mathrm{MS}^{2}$ stage, whereas PC species were identified at the $\mathrm{MS}^{3}$ stage [35]. HRMS spectra of PE molecular species are presented in detail as the examples of MS fragmentation (Figure 2A-D).

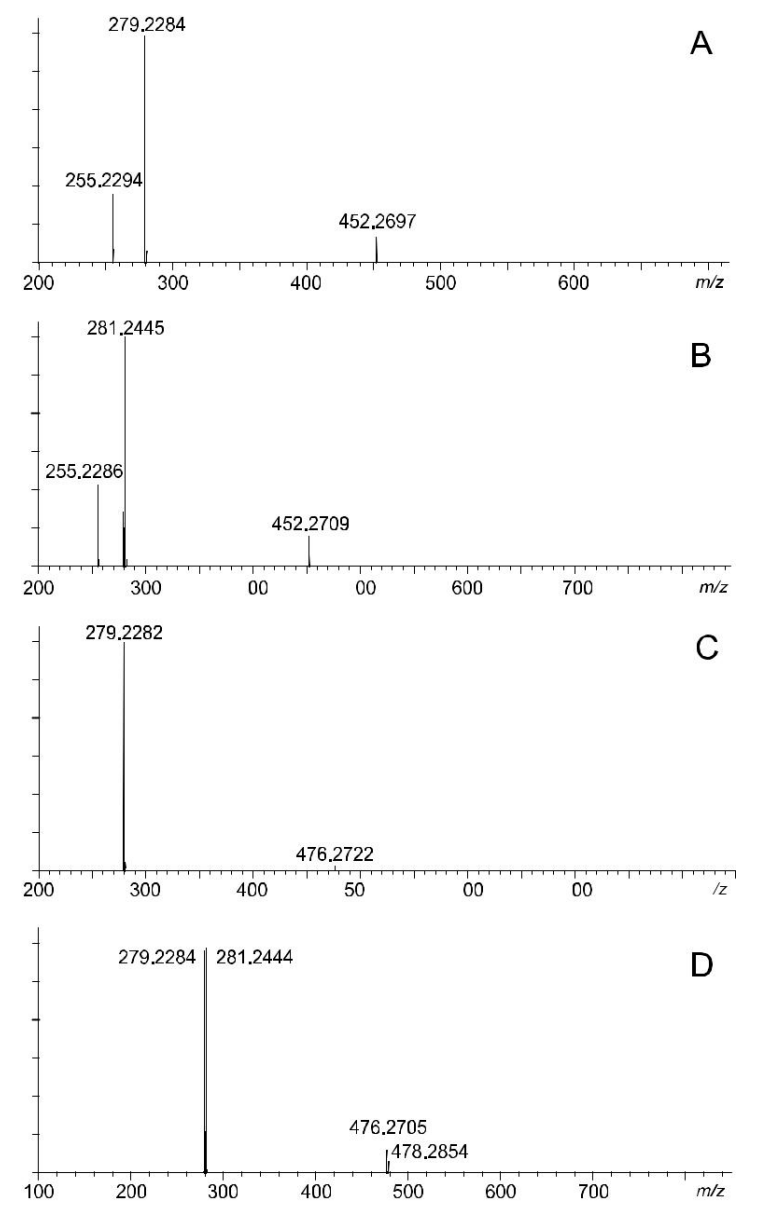

Figure 2. The high-resolution mass spectrometry (HRMS) spectra of (A) negative quasi-molecular ions $[\mathrm{M}-\mathrm{H}]^{-}$and $(\mathbf{B})$ positive cluster ions $\left[\mathrm{M}+\mathrm{H}+\left(\mathrm{C}_{2} \mathrm{H}_{5}\right)_{3} \mathrm{~N}\right]^{+}$of phosphatidylethanolamine (PE) molecular species, $\mathrm{MS}^{2}$ spectra of negative quasi-molecular ions $[\mathrm{M}-\mathrm{H}]^{-}$at $\mathrm{m} / \mathrm{z} 714.4988$ (A), 716.5163 (B), 738.4975 (C), and 740.5140 (D) corresponded to 16:0/18:2 PE, 16:0/18:1 PE, 18:2/18:2 PE, and 18:1/18:2 PE molecular species of phosphatidylethanolamine $\mathrm{MS}^{2}$ spectra of negative quasi-molecular ions $[\mathrm{M}-\mathrm{H}]^{-}$at $\mathrm{m} / \mathrm{z} 742.5296(\mathrm{~A})$ and $744.5436(\mathrm{C})$ corresponded to a mixture of 18:1/18:1 PE + 18:0/18:2 PE and 18:0/18:1 PE molecular species of phosphatidylethanolamine from Madhuca longifolia seeds. The sub-pictures (B) and (D) show the spectra in a large scale.

Phosphatidylethanolamine (PE). Six signals of negative quasi-molecular ions $[\mathrm{M}-\mathrm{H}]^{-}$at $\mathrm{m} / \mathrm{z}$ $714.4988,716.5163,738.4975,740.5140,742.5296$, and 744.5436 , as well as six signals of positive cluster ions $\left[\mathrm{M}+\mathrm{H}+\left(\mathrm{C}_{2} \mathrm{H}_{5}\right)_{3} \mathrm{~N}\right]^{+}$at $\mathrm{m} / \mathrm{z} 817.6365,819.6499,841.6331,843.6484,845.6627$, and 847.6749, were observed in the HRMS spectra of PE of M. ellitica seeds (Figure 1). Other less intensive peaks on Figure 1 corresponded to the signals of isotopic ions.

Six components were analyzed as described below. The $\mathrm{MS}^{2}$ spectrum of the ions $[\mathrm{M}-\mathrm{H}]^{-}$ of component 1 (m/z 714.4988) (Table 3) contained the signal at m/z 452.2697 formed by the loss of neutral fragment of $262.2291\left(\mathrm{C}_{18} \mathrm{H}_{30} \mathrm{O}\right.$, calculated 262.2297) (Figure 2A). This neutral fragment 
corresponded to dehydrated 18:2 acid. The $\mathrm{MS}^{2}$ spectrum also contained the signals of carboxylate anions of $16: 0$ and $18: 2$ acids at $\mathrm{m} / \mathrm{z} 255.2294\left(\left[\mathrm{C}_{16} \mathrm{H}_{31} \mathrm{O}_{2}\right]^{-}\right.$, calculated 255.2324) and $\mathrm{m} / \mathrm{z} 279.2284$ $\left(\left[\mathrm{C}_{18} \mathrm{H}_{31} \mathrm{O}_{2}\right]^{-}\right.$, calculated 279.2324), respectively. According to the elemental composition calculated and the value of monoisotopic molecular mass, component 1 was identified as palmitoyl linoleyl glycerophosphoethanolamine, 16:0/18:2 PE (Table 3). The $\mathrm{MS}^{2}$ spectrum of the ions $[\mathrm{M}-\mathrm{H}]^{-}$of component $2(\mathrm{~m} / \mathrm{z} 716.5163)$ contained the signal at $\mathrm{m} / \mathrm{z} 452.2713$ formed by the loss of neutral fragment of $264.2450\left(\mathrm{C}_{18} \mathrm{H}_{32} \mathrm{O}\right.$, calculated 264.2453) (Figure 2B). This neutral fragment corresponded to dehydrated 18:1 acid. The $\mathrm{MS}^{2}$ spectrum also contained the signals of carboxylate anions of 16:0 and 18:1 acids at $\mathrm{m} / \mathrm{z} 255.2294\left(\left[\mathrm{C}_{16} \mathrm{H}_{31} \mathrm{O}_{2}\right]^{-}\right.$, calculated 255.2324$)$ and $\mathrm{m} / \mathrm{z} 281.2443\left(\left[\mathrm{C}_{18} \mathrm{H}_{33} \mathrm{O}_{2}\right]^{-}\right.$, calculated 281.2480), respectively. Component 2 was identified as palmitoyl oleoyl glycerophosphoethanolamine, 16:0/18:1 PE (Table 1).

The $\mathrm{MS}^{2}$ spectrum of the ions $[\mathrm{M}-\mathrm{H}]^{-}$of component $3(\mathrm{~m} / \mathrm{z} 738.4975)$ contained the signal at $\mathrm{m} / \mathrm{z}$ 476.2778 formed by the loss of dehydrated 18:2 acid (262.2197, $\mathrm{C}_{18} \mathrm{H}_{30} \mathrm{O}$, calculated 262.2297) (Figure 2C). Only one signal of carboxylate anions at $\mathrm{m} / \mathrm{z} 279.2283\left(\left[\mathrm{C}_{18} \mathrm{H}_{31} \mathrm{O}_{2}\right]^{-}\right)$was found. This result showed that two acyl groups were identical. Component 3 was identified as dilinoleyl glycerophosphoethanolamine, 18:2/18:2 PE (Table 3).

The $\mathrm{MS}^{2}$ spectrum of the ions $[\mathrm{M}-\mathrm{H}]^{-}$of component $4(\mathrm{~m} / \mathrm{z} 740.5140)$ contained the signals at $\mathrm{m} / \mathrm{z}$ 478.2854 and 476.2705 formed by the loss of neutral fragments of dehydrated $18: 2\left(262.2286, \mathrm{C}_{18} \mathrm{H}_{30} \mathrm{O}\right.$, calculated 262.2297) and 18:1 acids (264.2435, $\mathrm{C}_{18} \mathrm{H}_{32} \mathrm{O}$, calculated 264.2453) (Figure 2D). The other two signals at $\mathrm{m} / \mathrm{z} 281.2444$ and 279.2284 were attributed to the anions of $18: 1$ and 18:2 acids, respectively. Component 4 was identified as oleoyl linoleyl glycerophosphoethanolamine, 18:1/18:2 PE (Table 3).

The MS² spectrum of component $5[\mathrm{M}-\mathrm{H}]^{-}, \mathrm{m} / \mathrm{z}$ 742.5296) contained six signals formed two compact groups (Figure 2A). Three major signals at $\mathrm{m} / \mathrm{z} 283.2545\left(\left[\mathrm{C}_{18} \mathrm{H}_{35} \mathrm{O}_{2}\right]^{-}\right), 281.2443\left(\left[\mathrm{C}_{18} \mathrm{H}_{33} \mathrm{O}_{2}\right]^{-}\right)$, and $279.2285\left(\left[\mathrm{C}_{18} \mathrm{H}_{31} \mathrm{O}_{2}\right]^{-}\right.$) (Figure $2 \mathrm{~B}$ ) corresponded to the anions of 18:0, 18:1, and 18:2 acids, respectively. Three weak signals at $\mathrm{m} / \mathrm{z} 478.2866,476.2707$, and 460.2808 were formed by the loss of neutral fragments of $264.2430\left(\mathrm{C}_{18} \mathrm{H}_{32} \mathrm{O}\right.$, calculated 264.2453), $266.2589\left(\mathrm{C}_{18} \mathrm{H}_{34} \mathrm{O}\right.$, calculated 266.261), and 282.2488 $\left(\mathrm{C}_{18} \mathrm{H}_{34} \mathrm{O}_{2}\right.$, calculated 282.2559), respectively.

These neutral fragments also originated from 18:1 and 18:2 acids. Component 5 was identified as a mixture of isomeric dioleoyl glycerophosphoethanolamine (18:1/18:1 PE) and stearoyl linoleyl glycerophosphoethanolamine, 18:0/18:2 PE (Table 3). The ratio between 18:1/18:1 PE and 18:0/18:2 $\mathrm{PE}$ was $4.4 / 1$ according to the intensity of the corresponding ion peaks. The $\mathrm{MS}^{2}$ spectrum of the ions $\left[\mathrm{M}-\mathrm{H}^{-}\right.$of component $6(\mathrm{~m} / \mathrm{z}$ 744.5436) showed the signals at $\mathrm{m} / \mathrm{z} 480.3046,283.2577$, and 281.2441 (Figure 2C,D). Similar to components 1 and 2, component 6 was identified as stearoyl oleoyl glycerophosphoethanolamine, 18:0/18:1 PE (Table 3).

Thus, seven PE molecular species, such as 16:0/18:2 PE, 16:0/18:1 PE, 18:2/18:2 PE, 18:1/18:2 PE, 18:1/18:1 PE, 18:0/18:2 PE, and 18:0/18:1 PE, were identified.

Phosphatidylcholine (PC). Six signals of negative acetylated molecular ions $\left[\mathrm{M}+\mathrm{CH}_{3} \mathrm{COO}\right]^{-}$at $\mathrm{m} / \mathrm{z} 816.5760,818.5889,820.5943,840.5712,842.5888$, and 844.6059 , as well as six corresponded signals of positive quasi-molecular ions $\left[\mathrm{M}+\mathrm{H}^{+}\right.$, were observed in the HRMS spectra of PC of M. ellitica seeds (Table 4). The ions $\left[\mathrm{M}+\mathrm{CH}_{3} \mathrm{COO}\right]^{-}$of each component lost methyl acetate $\left(\mathrm{CH}_{3} \mathrm{COOCH}_{3}\right)$ at the $\mathrm{MS}^{2}$ state. The subsequent fragmentation formed the anions characterized acyl groups of most components at the $\mathrm{MS}^{3}$ stage. In $\mathrm{MS}^{3}$ spectra of ions $\left[\mathrm{M}-\mathrm{H}-\mathrm{CH}_{3} \mathrm{COOCH}_{3}\right]^{-}$, the signals at $\mathrm{m} / \mathrm{z}$ 255.2320, 283.2602, 281.2474, and 279.2332 indicated the presence of acyl groups of 16:0, 18:0, 18:1, and 18:2 acids, respectively. According to the $\mathrm{MS}^{3}$ data, the elemental composition calculated, and the value of mono-isotopic molecular mass, we identified components 1,2 , and 5 as 16:0/18:2 PC, 16:0/18:1 PC, and 18:1/18:2 PC, respectively (Table 4). Component 6 were identified as a mixture of 18:1/18:1 PC and 18:0/18:2 PC with the ratio 1.58:1. We could not observe MS $^{3}$ fragmentation of components 3 and 4 because of their low concentration. We suggest that these components are 16:0/18:0 PC and 18:2/18:2 PC on the base of their elemental composition and mono-isotopic molecular mass (Table 4). 
Table 3. Molecular species of phosphatidylethanolamine (PE) from Madhuca ellitica seeds.

\begin{tabular}{|c|c|c|c|c|c|c|c|c|c|}
\hline \multirow{3}{*}{ No. } & \multirow{3}{*}{ Molecular Species } & \multicolumn{2}{|c|}{ ESI-MS } & \multicolumn{2}{|c|}{ Monoisotopic Molecular Mass } & \multirow{3}{*}{ Molecular Formula } & \multicolumn{3}{|c|}{$\overline{\mathrm{MS}^{2}}$} \\
\hline & & \multirow{2}{*}[\mathrm{M}+\mathrm{H}+\mathrm{Et}_{3}\mathrm{N}]{$^{+} \mathrm{m} / \mathbf{z}$} & \multirow{2}{*}[\mathbf{M}-\mathbf{H}]{$^{-} \mathbf{m} / \mathbf{z}$} & \multirow{2}{*}{ Measured } & \multirow{2}{*}{ Calculated } & & \multicolumn{2}{|c|}{ Fragment Ion $[\mathrm{M}-\mathrm{H}-\mathrm{X}]^{-*}$} & \multirow[b]{2}{*}{$x$} \\
\hline & & & & & & & $\mathbf{m} / \mathbf{z}$ & Composition & \\
\hline 1 & 16:0/18:2 PE & 817.6365 & 714.4988 & 715.5061 & 715.5152 & $\mathrm{C}_{39} \mathrm{H}_{74} \mathrm{NO}_{8} \mathrm{P}$ & $\begin{array}{l}52.2697 \\
279.2284 \\
255.2294 \\
\end{array}$ & $\begin{array}{c}\mathrm{C}_{21} \mathrm{H}_{44} \mathrm{NO}_{7} \mathrm{P} \\
\mathrm{C}_{18} \mathrm{H}_{31} \mathrm{O}_{2} \\
\mathrm{C}_{16} \mathrm{H}_{31} \mathrm{O}_{2} \\
\end{array}$ & $\begin{array}{c}\mathrm{C}_{18} \mathrm{H}_{30} \mathrm{O} \\
\mathrm{C}_{21} \mathrm{H}_{43} \mathrm{NO}_{6} \mathrm{P} \\
\mathrm{C}_{23} \mathrm{H}_{43} \mathrm{NO}_{6} \mathrm{P}\end{array}$ \\
\hline 2 & 16:0/18:1 PE & 819.6499 & 716.5163 & 717.5236 & 717.5309 & $\mathrm{C}_{39} \mathrm{H}_{76} \mathrm{NO}_{8} \mathrm{P}$ & $\begin{array}{l}52.2713 \\
281.2443 \\
255.2294 \\
\end{array}$ & $\begin{array}{c}\mathrm{C}_{21} \mathrm{H}_{44} \mathrm{NO}_{7} \mathrm{P} \\
\mathrm{C}_{18} \mathrm{H}_{33} \mathrm{O}_{2} \\
\mathrm{C}_{16} \mathrm{H}_{31} \mathrm{O}_{2}\end{array}$ & $\begin{array}{c}\mathrm{C}_{18} \mathrm{H}_{32} \mathrm{O} \\
\mathrm{C}_{21} \mathrm{H}_{43} \mathrm{NO}_{6} \mathrm{P} \\
\mathrm{C}_{23} \mathrm{H}_{45} \mathrm{NO}_{6} \mathrm{P}\end{array}$ \\
\hline 3 & 18:2/18:2 PE & 841.6331 & 738.4975 & 739.5048 & 739.5152 & $\mathrm{C}_{41} \mathrm{H}_{74} \mathrm{NO}_{8} \mathrm{P}$ & $\begin{array}{l}476.2778 \\
279.2283\end{array}$ & $\begin{array}{c}\mathrm{C}_{23} \mathrm{H}_{44} \mathrm{NO}_{7} \mathrm{P} \\
\mathrm{C}_{18} \mathrm{H}_{31} \mathrm{O}_{2}\end{array}$ & $\begin{array}{c}\mathrm{C}_{18} \mathrm{H}_{30} \mathrm{O} \\
\mathrm{C}_{23} \mathrm{H}_{43} \mathrm{NO}_{6} \mathrm{P}\end{array}$ \\
\hline 4 & 18:1/18:2 PE & 843.6484 & 740.5140 & 741.5213 & 741.5309 & $\mathrm{C}_{41} \mathrm{H}_{76} \mathrm{NO}_{8} \mathrm{P}$ & $\begin{array}{l}478.2854 \\
476.2705 \\
281.2444 \\
279.2284 \\
\end{array}$ & $\begin{array}{c}\mathrm{C}_{23} \mathrm{H}_{46} \mathrm{NO}_{7} \mathrm{P} \\
\mathrm{C}_{23} \mathrm{H}_{44} \mathrm{NO}_{7} \mathrm{P} \\
\mathrm{C}_{18} \mathrm{H}_{33} \mathrm{O}_{2} \\
\mathrm{C}_{18} \mathrm{H}_{31} \mathrm{O}_{2}\end{array}$ & $\begin{array}{c}\mathrm{C}_{18} \mathrm{H}_{30} \mathrm{O} \\
\mathrm{C}_{18} \mathrm{H}_{32} \mathrm{O} \\
\mathrm{C}_{23} \mathrm{H}_{43} \mathrm{NO}_{6} \mathrm{P} \\
\mathrm{C}_{23} \mathrm{H}_{45} \mathrm{NO}_{6} \mathrm{P}\end{array}$ \\
\hline 5 & $\begin{array}{l}\text { 18:1/18:1 PE (4.4) } \\
\text { 18:0/18:2 PE (1) }\end{array}$ & 845.6627 & 742.5296 & 743.5369 & 743.5465 & $\mathrm{C}_{41} \mathrm{H}_{78} \mathrm{NO}_{8} \mathrm{P}$ & $\begin{array}{l}478.2866 \\
476.2707 \\
460.2808 \\
283.2545 \\
281.2443 \\
279.2285 \\
\end{array}$ & $\begin{array}{c}\mathrm{C}_{23} \mathrm{H}_{46} \mathrm{NO}_{7} \mathrm{P} \\
\mathrm{C}_{23} \mathrm{H}_{44} \mathrm{NO}_{7} \mathrm{P} \\
\mathrm{C}_{23} \mathrm{H}_{44} \mathrm{NO}_{6} \mathrm{P} \\
\mathrm{C}_{18} \mathrm{H}_{35} \mathrm{O}_{2} \\
\mathrm{C}_{18} \mathrm{H}_{33} \mathrm{O}_{2} \\
\mathrm{C}_{18} \mathrm{H}_{31} \mathrm{O}_{2}\end{array}$ & $\begin{array}{c}\mathrm{C}_{18} \mathrm{H}_{32} \mathrm{O} \\
\mathrm{C}_{18} \mathrm{H}_{34} \mathrm{O} \\
\mathrm{C}_{18} \mathrm{H}_{34} \mathrm{O}_{2} \\
\mathrm{C}_{23} \mathrm{H}_{43} \mathrm{NO}_{6} \mathrm{P} \\
\mathrm{C}_{23} \mathrm{H}_{45} \mathrm{NO}_{6} \mathrm{P} \\
\mathrm{C}_{23} \mathrm{H}_{47} \mathrm{NO}_{6} \mathrm{P}\end{array}$ \\
\hline 6 & 18:0/18:1 PE & 847.6749 & 744.5436 & 745.5509 & 745.5622 & $\mathrm{C}_{41} \mathrm{H}_{80} \mathrm{NO}_{8} \mathrm{P}$ & $\begin{array}{l}480.3046 \\
283.2577 \\
281.2441\end{array}$ & $\begin{array}{c}\mathrm{C}_{23} \mathrm{H}_{48} \mathrm{NO}_{7} \mathrm{P} \\
\mathrm{C}_{18} \mathrm{H}_{35} \mathrm{O}_{2} \\
\mathrm{C}_{18} \mathrm{H}_{33} \mathrm{O}_{2}\end{array}$ & $\begin{array}{c}\mathrm{C}_{18} \mathrm{H}_{32} \mathrm{O} \\
\mathrm{C}_{23} \mathrm{H}_{45} \mathrm{NO}_{6} \mathrm{P} \\
\mathrm{C}_{23} \mathrm{H}_{47} \mathrm{NO}_{6} \mathrm{P}\end{array}$ \\
\hline
\end{tabular}

ESI-MS: electrospray ionization-mass spectrometry. ${ }^{*}$ Precursor ion $[\mathrm{M}-\mathrm{H}]^{-}$. 
Table 4. Molecular species of phosphatidylcholine (PC) from Madhuca ellitica seeds.

\begin{tabular}{|c|c|c|c|c|c|c|c|c|}
\hline \multirow{3}{*}{ No. } & \multirow{3}{*}{ Molecular Species } & \multirow{3}{*}{$\frac{\text { ESI-MS }}{\left[\mathrm{M}+\mathrm{CH}_{3} \mathrm{COO}^{-} \mathrm{m} / \mathrm{z}\right.}$} & \multicolumn{2}{|c|}{ Monoisotopic Molecular Mass } & \multirow{3}{*}{ Molecular Formula } & \multirow{3}{*}{$\begin{array}{c}\text { MS }^{2} \\
\text { Fragment Ion } \\
\\
{\left[\mathrm{M}+\mathrm{CH}_{3} \mathrm{COO}-\mathrm{C}_{3} \mathrm{H}_{6} \mathrm{O}_{2}\right]^{-} \mathrm{m} / \mathrm{z}}\end{array}$} & \multirow{2}{*}{\multicolumn{2}{|c|}{$\begin{array}{c}\mathrm{MS}^{3} \\
\text { Fragmentation }^{* *} \\
\end{array}$}} \\
\hline & & & \multirow{2}{*}{ Measured } & \multirow{2}{*}{ Calculated } & & & & \\
\hline & & & & & & & $\mathbf{m} / \mathbf{z}$ & Composition \\
\hline 1 & 16:0/18:2 PC & 816.5760 & 757.5621 & 757.5622 & $\mathrm{C}_{42} \mathrm{H}_{80} \mathrm{NO}_{8} \mathrm{P}$ & 742.5389 & 279.2274 & $\mathrm{C}_{18} \mathrm{H}_{31} \mathrm{O}_{2}$ \\
\hline 2 & 16:0/18:1 PC & 818.5889 & 759.5750 & 759.5778 & $\mathrm{C}_{42} \mathrm{H}_{82} \mathrm{NO}_{8} \mathrm{P}$ & 744.5532 & $\begin{array}{l}281.2462 \\
255.2320 \\
\end{array}$ & $\begin{array}{l}\mathrm{C}_{18} \mathrm{H}_{33} \mathrm{O}_{2} \\
\mathrm{C}_{16} \mathrm{H}_{31} \mathrm{O}_{2} \\
\end{array}$ \\
\hline 3 & 16:0/18:0 PC & 820.5943 & 761.5804 & 761.5935 & $\mathrm{C}_{42} \mathrm{H}_{84} \mathrm{NO}_{8} \mathrm{P}$ & 746.5599 & ND & - \\
\hline 4 & 18:2/18:2 PC & 840.5712 & 781.5573 & 781.5622 & $\mathrm{C}_{44} \mathrm{H}_{80} \mathrm{NO}_{8} \mathrm{P}$ & 766.5309 & ND & - \\
\hline 5 & 18:1/18:2 PC & 842.5888 & 783.5749 & 783.5778 & $\mathrm{C}_{44} \mathrm{H}_{82} \mathrm{NO}_{8} \mathrm{P}$ & 768.5511 & $\begin{array}{l}281.2432 \\
279.2352\end{array}$ & $\begin{array}{l}\mathrm{C}_{18} \mathrm{H}_{33} \mathrm{O}_{2} \\
\mathrm{C}_{18} \mathrm{H}_{31} \mathrm{O}_{2}\end{array}$ \\
\hline 6 & $\begin{array}{l}\text { 18:1/18:1 PC (1.58) } \\
\text { 18:0/18:2 PC (1) }\end{array}$ & 844.6059 & 785.5920 & 785.5935 & $\mathrm{C}_{44} \mathrm{H}_{84} \mathrm{NO}_{8} \mathrm{P}$ & 770.5674 & $\begin{array}{l}283.2602 \\
281.2474 \\
279.2332\end{array}$ & $\begin{array}{l}\mathrm{C}_{18} \mathrm{H}_{35} \mathrm{O}_{2} \\
\mathrm{C}_{18} \mathrm{H}_{33} \mathrm{O}_{2} \\
\mathrm{C}_{18} \mathrm{H}_{31} \mathrm{O}_{2}\end{array}$ \\
\hline
\end{tabular}

ND: not detected. * Precursor ion $\left[\mathrm{M}+\mathrm{CH}_{3} \mathrm{COO}\right]^{-} .{ }^{* *}$ Precursor ion $\left[\mathrm{M}+\mathrm{CH}_{3} \mathrm{COO}-\mathrm{C}_{3} \mathrm{H}_{6} \mathrm{O}_{2}\right]^{-}$. 
Phosphatidylinositol (PI). The main molecular species of PI from $M$. ellitica seeds produced five negative quasi-molecular ions $[\mathrm{M}-\mathrm{H}]^{-}$at $\mathrm{m} / \mathrm{z} 833.5188\left(\left[\mathrm{C}_{43} \mathrm{H}_{78} \mathrm{O}_{13} \mathrm{P}\right]^{-}\right), 835.5328\left(\left[\mathrm{C}_{43} \mathrm{H}_{80} \mathrm{O}_{13} \mathrm{P}\right]^{-}\right)$, $857.5155\left(\left[\mathrm{C}_{45} \mathrm{H}_{78} \mathrm{O}_{13} \mathrm{P}\right]^{-}\right), 861.5463\left(\left[\mathrm{C}_{45} \mathrm{H}_{80} \mathrm{O}_{13} \mathrm{P}\right]^{-}\right), 863.5635\left(\left[\mathrm{C}_{45} \mathrm{H}_{82} \mathrm{O}_{13} \mathrm{P}\right]^{-}\right)$(Table 5). These five components constituted more than $96 \%$ of total PI. Positive quasi-molecular ions also formed.

$\mathrm{MS}^{2}$ fragmentation of the ions $[\mathrm{M}-\mathrm{H}]^{-}$of PI were more complex than that of PE or PC and gave more ions. Generally, the $\mathrm{MS}^{2}$ spectra the ions $[\mathrm{M}-\mathrm{H}]^{-}$of PI contained the signals of FA carboxylate anions and several fragments, which arise from the loss of each FA, each dehydrated FA, two FAs, two dehydrated FAs, and different combinations of inositol and acyl fragments.

As an example, $\mathrm{MS}^{2}$ fragmentation of the ions $[\mathrm{M}-\mathrm{H}]^{-}$of component $1(\mathrm{~m} / \mathrm{z} 833.5188)$ is explained in detail (Table 5). The ions at $\mathrm{m} / \mathrm{z} 281.2474\left[\mathrm{C}_{18} \mathrm{H}_{33} \mathrm{O}_{2}\right]^{-}, 279.2307\left[\mathrm{C}_{18} \mathrm{H}_{31} \mathrm{O}_{2}\right]^{-}$, and 255.2346 $\left[\mathrm{C}_{16} \mathrm{H}_{31} \mathrm{O}_{2}\right]^{-}$corresponded to carboxylate anions of $18: 1,18: 2$, and 16:0, respectively.

The loss of neutral acids 16:1, 16:0, and 18:2 gave ions at $\mathrm{m} / \mathrm{z} 579.2901\left(\left[\mathrm{M}-\mathrm{H}-\mathrm{C}_{16} \mathrm{H}_{32} \mathrm{O}_{2}\right]^{-}\right.$), 577.2784 ( $\left[\left[\mathrm{M}-\mathrm{H}-\mathrm{C}_{16} \mathrm{H}_{30} \mathrm{O}_{2}\right]^{-}\right)$, and $553.2813\left(\left[\mathrm{M}-\mathrm{H}-\mathrm{C}_{18} \mathrm{H}_{32} \mathrm{O}_{2}\right]^{-}\right.$, calculated 553.2783), respectively. The loss of dehydrated 18:2 and 16:0 led to the formation of ions at $\mathrm{m} / \mathrm{z} 571.2904\left(\left[\mathrm{M}-\mathrm{H}-\mathrm{C}_{18} \mathrm{H}_{30} \mathrm{O}\right]^{-}\right)$ and $595.2769\left(\left[\mathrm{M}-\mathrm{H}-\mathrm{C}_{18} \mathrm{H}_{30} \mathrm{O}\right]^{-}\right)$, respectively. The appearance of ions at $\mathrm{m} / \mathrm{z} 297.0388$ (calculated 297.0381) was caused by the simultaneous loss of $16: 0$ and $18: 2$ (or $16: 1$ and $18: 1$ ). The ions at $\mathrm{m} / \mathrm{z}$ 315.0464 (calculated 315.0487) were formed by the simultaneous loss of dehydrated 16:0 and 18:2 (or 16:1 and 18:1). The loss of inositol and acyl fragments, namely $\left(\left[\mathrm{C}_{6} \mathrm{H}_{10} \mathrm{O}_{5}+\mathrm{C}_{16} \mathrm{H}_{30} \mathrm{O}_{2}\right],\left(\left[\mathrm{C}_{6} \mathrm{H}_{10} \mathrm{O}_{5}\right.\right.\right.$ $\left.+\mathrm{C}_{16} \mathrm{H}_{32} \mathrm{O}_{2}\right]$, and $\left(\left[\mathrm{C}_{6} \mathrm{H}_{10} \mathrm{O}_{5}+\mathrm{C}_{18} \mathrm{H}_{32} \mathrm{O}_{2}\right]\right.$, gave the ions at $\mathrm{m} / \mathrm{z} 417.2418,415.2268$, and 391.2253, respectively, characteristic for PI. Thus, compound 1 was identified as a mixture of 16:1/18:1 PI and 16:0/18:2 PI. Similar to our approach described above, compounds 2, 3, and 5 were identified as individual 16:0/18:1 PI, 18:2/18:2 PI, and 18:0/18:1 PI, respectively, whereas compound 4 contained a mixture of 18:0/18:2 PI and 18:1/18:1 PI (Table 5).

Phosphatidylglycerol (PG). Molecular species of PG of $M$. ellitica seeds were identified according to the monoisotopic molecular mass of negative quasi-molecular ions $[\mathrm{M}-\mathrm{H}]^{-}$, their elemental compositions, and $\mathrm{MS}^{2}$ fragmentation indicated acyl groups of PG molecules. Six major signals of the negative quasi-molecular ions $[\mathrm{M}-\mathrm{H}]^{-}$at $\mathrm{m} / \mathrm{z} 745.4944,747.5092,749.5212,771.5092,773.5253$, and 775.5380 were observed in the HRMS spectra (Table 6). $\mathrm{MS}^{2}$ spectra of the ions $[\mathrm{M}-\mathrm{H}]^{-}$contained the signals of carboxylate anions of $16: 0\left(\left[\mathrm{C}_{16} \mathrm{H}_{31} \mathrm{O}_{2}\right]^{-}\right), 18: 0\left(\left[\mathrm{C}_{18} \mathrm{H}_{35} \mathrm{O}_{2}\right]^{-}\right), 18: 1\left(\left[\mathrm{C}_{18} \mathrm{H}_{33} \mathrm{O}_{2}\right]^{-}\right)$, and 18:2 $\left(\left[\mathrm{C}_{18} \mathrm{H}_{31} \mathrm{O}_{2}\right]^{-}\right)$acids. The signals of the ions, which lost neutral FAs, or dehydrated FAs, or glycerol fragment $\left(\mathrm{C}_{3} \mathrm{H}_{6} \mathrm{O}_{2}\right)$ were also observed in some $\mathrm{MS}^{2}$ spectra of the ions $[\mathrm{M}-\mathrm{H}]^{-}$of PI molecular species. According to MS/MS data, the molecular species 16:0/18:0 PG, 16:0/18:1 PG, 16:0/18:2 PG, 18:0/18:1 PG, 18:0/18:2 PG, 18:1/18:1 PG, and 18:1/18:2 PG were identified (Table 6). These seven molecular species constituted about $99 \%$ of total PG.

Phosphatidic acid (PA). Six signals of the negative quasi-molecular ions $[\mathrm{M}-\mathrm{H}]^{-}$at $\mathrm{m} / \mathrm{z} 671.4643$, 673.4798, 695.4660, 697.4803, 699.4949, and 701.5098 were detected in the HRMS spectra of molecular species of PA from M. ellitica seeds (Table 7). Similar to other phospholipid classes, $\mathrm{MS}^{2}$ spectra of the ions $[\mathrm{M}-\mathrm{H}]^{-}$of PA contained the signals of carboxylate anions of 16:0 $\left(\left[\mathrm{C}_{16} \mathrm{H}_{31} \mathrm{O}_{2}\right]^{-}\right), 18: 0$ $\left(\left[\mathrm{C}_{18} \mathrm{H}_{35} \mathrm{O}_{2}\right]^{-}\right), 18: 1\left(\left[\mathrm{C}_{18} \mathrm{H}_{33} \mathrm{O}_{2}\right]^{-}\right)$, and 18:2 $\left(\left[\mathrm{C}_{18} \mathrm{H}_{31} \mathrm{O}_{2}\right]^{-}\right)$acids. The signals of the ions $[\mathrm{M}-\mathrm{H}]^{-}$, which lost two neutral FAs or two dehydrated FAs, were also observed in these $\mathrm{MS}^{2}$ spectra. The components, which produced ions related to three FAs, were considered as a mixture of two isotopes. For example, compound $5\left(\mathrm{~m} / \mathrm{z}\right.$ 699.4949, $\left.[\mathrm{M}-\mathrm{H}]^{-}\right)$was identified as a mixture of 18:1/18:1 PA and 18:0/18:2 PA. On the whole, the molecular species 16:0/18:1 PA, 16:0/18:2 PA, 18:0/18:1 PA, 18:0/18:2 PA, 18:1/18:1 PA, 18:1/18:2 PA, and 18:2/18:2 PA were identified (Table 7). 
Table 5. Molecular species of phosphatidylinositol (PI) from Madhuca ellitica seeds.

\begin{tabular}{|c|c|c|c|c|c|c|c|}
\hline \multirow[b]{2}{*}{ No. } & \multirow{2}{*}{ Molecular Species } & \multirow{2}{*}{$\begin{array}{c}\text { ESI-MS } \\
{\left[\mathbf{M}-\mathbf{H}^{-} \mathrm{m} / \mathbf{z}\right.}\end{array}$} & \multicolumn{2}{|c|}{ Monoisotopic Molecular Mass } & \multirow{2}{*}{ Molecular Formula } & \multicolumn{2}{|r|}{$\mathrm{MS}^{2}$} \\
\hline & & & Measured & Calculated & & $\begin{array}{c}\text { Fragment Ion * } \\
{[\mathrm{M}-\mathrm{H}-\mathrm{X}]^{-} \mathrm{m} / \mathbf{z}}\end{array}$ & $x$ \\
\hline 1 & $\begin{array}{l}\text { 16:1/18:1 PI } \\
\text { 16:0/18:2 PI }\end{array}$ & 833.5188 & 834.5256 & 834.5258 & $\mathrm{C}_{43} \mathrm{H}_{79} \mathrm{O}_{13} \mathrm{P}$ & $\begin{array}{l}595.2769 \\
579.2901 \\
577.2784 \\
571.2904 \\
553.2813 \\
417.2418 \\
415.2268 \\
409.2352 \\
391.2253 \\
297.0388 \\
281.2474 \\
279.2307 \\
255.2346 \\
\end{array}$ & $\begin{array}{c}\mathrm{C}_{16} \mathrm{H}_{30} \mathrm{O} \\
\mathrm{C}_{16} \mathrm{H}_{30} \mathrm{O}_{2} \\
\mathrm{C}_{16} \mathrm{H}_{32} \mathrm{O}_{2} \\
\mathrm{C}_{18} \mathrm{H}_{30} \mathrm{O} \\
\mathrm{C}_{18} \mathrm{H}_{30} \mathrm{O}_{2} \\
\mathrm{C}_{22} \mathrm{H}_{40} \mathrm{O}_{7}\left(\mathrm{C}_{6} \mathrm{H}_{10} \mathrm{O}_{5}+\mathrm{C}_{16} \mathrm{H}_{30} \mathrm{O}_{2}\right) \\
\mathrm{C}_{22} \mathrm{H}_{42} \mathrm{O}_{7}\left(\mathrm{C}_{6} \mathrm{H}_{10} \mathrm{O}_{5}+\mathrm{C}_{16} \mathrm{H}_{32} \mathrm{O}_{2}\right) \\
\mathrm{C}_{24} \mathrm{H}_{40} \mathrm{O}_{6}\left(\mathrm{C}_{6} \mathrm{H}_{10} \mathrm{O}_{5}+\mathrm{C}_{18} \mathrm{H}_{30} \mathrm{O}\right) \\
\mathrm{C}_{24} \mathrm{H}_{42} \mathrm{O}_{7}\left(\mathrm{C}_{6} \mathrm{H}_{10} \mathrm{O}_{5}+\mathrm{C}_{18} \mathrm{H}_{32} \mathrm{O}_{2}\right) \\
\mathrm{C}_{34} \mathrm{H}_{64} \mathrm{O}_{4}\left(\mathrm{C}_{16} \mathrm{H}_{32} \mathrm{O}_{2}+\mathrm{C}_{18} \mathrm{H}_{32} \mathrm{O}_{2}\right) \\
\mathrm{C}_{25} \mathrm{H}_{45} \mathrm{O}_{11} \mathrm{P} \\
\mathrm{C}_{25} \mathrm{H}_{47} \mathrm{O}_{11} \mathrm{P} \\
\mathrm{C}_{27} \mathrm{H}_{47} \mathrm{O}_{11} \mathrm{P}\end{array}$ \\
\hline 2 & 16:0/18:1 PI & 835.5328 & 836.5401 & 836.5415 & $\mathrm{C}_{43} \mathrm{H}_{81} \mathrm{O}_{13} \mathrm{P}$ & $\begin{array}{l}597.3036 \\
579.2939 \\
571.2876 \\
553.2805 \\
435.2438 \\
417.2389 \\
409.2351 \\
391.2250 \\
297.0373 \\
281.2484 \\
255.2337 \\
\end{array}$ & $\begin{array}{c}\mathrm{C}_{16} \mathrm{H}_{30} \mathrm{O} \\
\mathrm{C}_{16} \mathrm{H}_{32} \mathrm{O}_{2} \\
\mathrm{C}_{18} \mathrm{H}_{32} \mathrm{O} \\
\mathrm{C}_{18} \mathrm{H}_{34} \mathrm{O}_{2} \\
\mathrm{C}_{22} \mathrm{H}_{40} \mathrm{O}_{6}\left(\mathrm{C}_{6} \mathrm{H}_{10} \mathrm{O}_{5}+\mathrm{C}_{16} \mathrm{H}_{30} \mathrm{O}\right) \\
\mathrm{C}_{22} \mathrm{H}_{42} \mathrm{O}_{7}\left(\mathrm{C}_{6} \mathrm{H}_{10} \mathrm{O}_{5}+\mathrm{C}_{16} \mathrm{H}_{32} \mathrm{O}_{2}\right) \\
\mathrm{C}_{24} \mathrm{H}_{42} \mathrm{O}_{6}\left(\mathrm{C}_{6} \mathrm{H}_{10} \mathrm{O}_{5}+\mathrm{C}_{18} \mathrm{H}_{32} \mathrm{O}\right) \\
\mathrm{C}_{24} \mathrm{H}_{44} \mathrm{O}_{7}\left(\mathrm{C}_{6} \mathrm{H}_{10} \mathrm{O}_{5}+\mathrm{C}_{18} \mathrm{H}_{34} \mathrm{O}_{2}\right) \\
\mathrm{C}_{34} \mathrm{H}_{64} \mathrm{O}_{4}\left(\mathrm{C}_{16} \mathrm{H}_{32} \mathrm{O}_{2}+\mathrm{C}_{18} \mathrm{H}_{34} \mathrm{O}_{2}\right) \\
\mathrm{C}_{25} \mathrm{H}_{47} \mathrm{O}_{11} \mathrm{P} \\
\mathrm{C}_{27} \mathrm{H}_{49} \mathrm{O}_{11} \mathrm{P} \\
\end{array}$ \\
\hline 3 & 18:2/18:2 PI & 857.5155 & 858.5228 & 858.5258 & $\mathrm{C}_{45} \mathrm{H}_{79} \mathrm{O}_{13} \mathrm{P}$ & $\begin{array}{l}577.2805 \\
415.2264 \\
279.2337\end{array}$ & $\begin{array}{c}\mathrm{C}_{18} \mathrm{H}_{32} \mathrm{O}_{2} \\
\mathrm{C}_{24} \mathrm{H}_{42} \mathrm{O}_{7}\left(\mathrm{C}_{6} \mathrm{H}_{10} \mathrm{O}_{5}+\mathrm{C}_{18} \mathrm{H}_{32} \mathrm{O}_{2}\right) \\
\mathrm{C}_{27} \mathrm{H}_{47} \mathrm{O}_{11} \mathrm{P}\end{array}$ \\
\hline
\end{tabular}


Table 5. Cont.

\begin{tabular}{|c|c|c|c|c|c|c|c|}
\hline \multirow{2}{*}{ No. } & \multirow{2}{*}{ Molecular Species } & \multirow{2}{*}{$\frac{\text { ESI-MS }}{[\mathrm{M}-\mathrm{H}]^{-} \mathrm{m} / \mathrm{z}}$} & \multicolumn{2}{|c|}{ Monoisotopic Molecular Mass } & \multirow{2}{*}{ Molecular Formula } & \multicolumn{2}{|r|}{ MS $^{2}$} \\
\hline & & & Measured & Calculated & & $\begin{array}{l}\text { Fragment Ion * } \\
{[\mathrm{M}-\mathrm{H}-\mathrm{X}]^{-} \mathrm{m} / \mathrm{z}}\end{array}$ & $X$ \\
\hline 4 & $\begin{array}{l}\text { 18:0/18:2 PI } \\
\text { 18:1/18:1 PI }\end{array}$ & 861.5463 & 862.5536 & 862.5571 & $\mathrm{C}_{45} \mathrm{H}_{81} \mathrm{O}_{13} \mathrm{P}$ & $\begin{array}{l}599.3202 \\
597.3037 \\
595.2894 \\
581.3095 \\
579.2945 \\
577.2775 \\
437.2665 \\
435.2511 \\
433.2306 \\
419.2571 \\
417.2394 \\
415.2241 \\
297.0370 \\
283.2622 \\
281.2484 \\
279.2328\end{array}$ & $\begin{array}{c}\mathrm{C}_{18} \mathrm{H}_{30} \mathrm{O} \\
\mathrm{C}_{18} \mathrm{H}_{32} \mathrm{O} \\
\mathrm{C}_{18} \mathrm{H}_{34} \mathrm{O} \\
\mathrm{C}_{18} \mathrm{H}_{32} \mathrm{O}_{2} \\
\mathrm{C}_{18} \mathrm{H}_{34} \mathrm{O}_{2} \\
\mathrm{C}_{18} \mathrm{H}_{36} \mathrm{O}_{2} \\
\mathrm{C}_{24} \mathrm{H}_{40} \mathrm{O}_{6}\left(\mathrm{C}_{6} \mathrm{H}_{10} \mathrm{O}_{5}+\mathrm{C}_{18} \mathrm{H}_{30} \mathrm{O}\right) \\
\mathrm{C}_{24} \mathrm{H}_{42} \mathrm{O}_{6}\left(\mathrm{C}_{6} \mathrm{H}_{10} \mathrm{O}_{5}+\mathrm{C}_{18} \mathrm{H}_{32} \mathrm{O}\right) \\
\mathrm{C}_{24} \mathrm{H}_{44} \mathrm{O}_{6}\left(\mathrm{C}_{6} \mathrm{H}_{10} \mathrm{O}_{5}+\mathrm{C}_{18} \mathrm{H}_{34} \mathrm{O}\right) \\
\mathrm{C}_{24} \mathrm{H}_{42} \mathrm{O}_{7}\left(\mathrm{C}_{6} \mathrm{H}_{10} \mathrm{O}_{5}+\mathrm{C}_{18} \mathrm{H}_{32} \mathrm{O}_{2}\right) \\
\mathrm{C}_{24} \mathrm{H}_{44} \mathrm{O}_{7}\left(\mathrm{C}_{6} \mathrm{H}_{10} \mathrm{O}_{5}+\mathrm{C}_{18} \mathrm{H}_{34} \mathrm{O}_{2}\right) \\
\mathrm{C}_{24} \mathrm{H}_{46} \mathrm{O}_{7}\left(\mathrm{C}_{6} \mathrm{H}_{10} \mathrm{O}_{5}+\mathrm{C}_{18} \mathrm{H}_{36} \mathrm{O}_{2}\right) \\
\mathrm{C}_{36} \mathrm{H}_{68} \mathrm{O}_{4} \\
\mathrm{C}_{27} \mathrm{H}_{45} \mathrm{O}_{11} \mathrm{P} \\
\mathrm{C}_{27} \mathrm{H}_{47} \mathrm{O}_{11} \mathrm{P} \\
\mathrm{C}_{27} \mathrm{H}_{49} \mathrm{O}_{11} \mathrm{P}\end{array}$ \\
\hline 5 & 18:0/18:1 PI & 863.5635 & 864.5708 & 864.5728 & $\mathrm{C}_{45} \mathrm{H}_{83} \mathrm{O}_{13} \mathrm{P}$ & $\begin{array}{l}701.5027 \\
599.3203 \\
597.3032 \\
581.3097 \\
579.2943 \\
419.2573 \\
417.2393 \\
297.0376 \\
283.2627 \\
281.2485\end{array}$ & $\begin{array}{c}\mathrm{C}_{6} \mathrm{H}_{10} \mathrm{O}_{5} \\
\mathrm{C}_{18} \mathrm{H}_{32} \mathrm{O} \\
\mathrm{C}_{18} \mathrm{H}_{34} \mathrm{O} \\
\mathrm{C}_{18} \mathrm{H}_{34} \mathrm{O}_{2} \\
\mathrm{C}_{18} \mathrm{H}_{36} \mathrm{O}_{2} \\
\mathrm{C}_{24} \mathrm{H}_{44} \mathrm{O}_{7}\left(\mathrm{C}_{6} \mathrm{H}_{10} \mathrm{O}_{5}+\mathrm{C}_{18} \mathrm{H}_{34} \mathrm{O}_{2}\right) \\
\mathrm{C}_{24} \mathrm{H}_{46} \mathrm{O}_{7}\left(\mathrm{C}_{6} \mathrm{H}_{10} \mathrm{O}_{5}+\mathrm{C}_{18} \mathrm{H}_{36} \mathrm{O}_{2}\right) \\
\mathrm{C}_{36} \mathrm{H}_{70} \mathrm{O}_{4} \\
\mathrm{C}_{27} \mathrm{H}_{47} \mathrm{O}_{11} \mathrm{P} \\
\mathrm{C}_{27} \mathrm{H}_{49} \mathrm{O}_{11} \mathrm{P}\end{array}$ \\
\hline
\end{tabular}

* Precursor ion $[\mathrm{M}-\mathrm{H}]^{-}$. 
Table 6. Molecular species of phosphatidylglycerol (PG) from Madhuca ellitica seeds.

\begin{tabular}{|c|c|c|c|c|c|c|c|}
\hline \multirow{2}{*}{ No. } & \multirow{2}{*}{ Molecular Species } & \multirow{2}{*}{$\begin{array}{c}\text { ESI-MS } \\
{[\mathbf{M}-\mathbf{H}]^{-} \mathbf{m} / \mathbf{z}}\end{array}$} & \multicolumn{2}{|c|}{ Monoisotopic Molecular Mass } & \multirow{2}{*}{ Molecular Formula } & \multicolumn{2}{|r|}{ MS $^{2}$} \\
\hline & & & Measured & Calculated & & $\begin{array}{l}\text { Fragment Ion * } \\
{[\mathrm{M}-\mathbf{H}-\mathbf{X}]^{-} \mathrm{m} / \mathbf{z}}\end{array}$ & $x$ \\
\hline 1 & 16:0/18:2 PG & 745.4944 & 746.5017 & 746.5098 & $\mathrm{C}_{40} \mathrm{H}_{75} \mathrm{O}_{10} \mathrm{P}$ & $\begin{array}{l}391.2224 \\
279.2303 \\
255.2336 \\
\end{array}$ & $\begin{array}{c}\mathrm{C}_{21} \mathrm{H}_{38} \mathrm{O}_{4}\left(\mathrm{C}_{3} \mathrm{H}_{6} \mathrm{O}_{2}+\mathrm{C}_{18} \mathrm{H}_{32} \mathrm{O}_{2}\right) \\
\mathrm{C}_{22} \mathrm{H}_{43} \mathrm{O}_{8} \mathrm{P} \\
\mathrm{C}_{24} \mathrm{H}_{43} \mathrm{O}_{8} \mathrm{P}\end{array}$ \\
\hline 2 & 16:0/18:1 PG & 747.5092 & 748.5164 & 748.5254 & $\mathrm{C}_{40} \mathrm{H}_{77} \mathrm{O}_{10} \mathrm{P}$ & $\begin{array}{l}281.2482 \\
255.2323 \\
\end{array}$ & $\begin{array}{l}\mathrm{C}_{22} \mathrm{H}_{43} \mathrm{O}_{8} \mathrm{P} \\
\mathrm{C}_{24} \mathrm{H}_{45} \mathrm{O}_{8} \mathrm{P} \\
\end{array}$ \\
\hline 3 & 16:0/18:0 PG & 749.5212 & 750.5285 & 750.5411 & $\mathrm{C}_{40} \mathrm{H}_{79} \mathrm{O}_{10} \mathrm{P}$ & $\begin{array}{l}283.2598 \\
255.2321 \\
\end{array}$ & $\begin{array}{l}\mathrm{C}_{22} \mathrm{H}_{43} \mathrm{O}_{8} \mathrm{P} \\
\mathrm{C}_{24} \mathrm{H}_{47} \mathrm{O}_{8} \mathrm{P} \\
\end{array}$ \\
\hline 4 & 18:1/18:2 PG & 771.5092 & 772.5164 & 772.5254 & $\mathrm{C}_{42} \mathrm{H}_{77} \mathrm{O}_{10} \mathrm{P}$ & $\begin{array}{l}491.2788 \\
281.2477 \\
279.2325 \\
\end{array}$ & $\begin{array}{l}\mathrm{C}_{18} \mathrm{H}_{32} \mathrm{O}_{2} \\
\mathrm{C}_{24} \mathrm{H}_{43} \mathrm{O}_{8} \mathrm{P} \\
\mathrm{C}_{24} \mathrm{H}_{45} \mathrm{O}_{8} \mathrm{P}\end{array}$ \\
\hline 5 & $\begin{array}{l}\text { 18:1/18:1 PG } \\
18: 0 / 18: 2 \text { PG }\end{array}$ & 773.5253 & 774.5326 & 774.5411 & $\mathrm{C}_{42} \mathrm{H}_{79} \mathrm{O}_{10} \mathrm{P}$ & $\begin{array}{l}283.2598 \\
281.2478 \\
279.2328 \\
\end{array}$ & $\begin{array}{l}\mathrm{C}_{24} \mathrm{H}_{43} \mathrm{O}_{8} \mathrm{P} \\
\mathrm{C}_{24} \mathrm{H}_{45} \mathrm{O}_{8} \mathrm{P} \\
\mathrm{C}_{24} \mathrm{H}_{47} \mathrm{O}_{8} \mathrm{P} \\
\end{array}$ \\
\hline 6 & 18:0/18:1 PG & 775.5380 & 776.5524 & 776.5567 & $\mathrm{C}_{42} \mathrm{H}_{81} \mathrm{O}_{10} \mathrm{P}$ & $\begin{array}{l}493.2940 \\
491.2773 \\
419.2554 \\
417.2406 \\
283.2608 \\
281.2478\end{array}$ & $\begin{array}{c}\mathrm{C}_{18} \mathrm{H}_{34} \mathrm{O}_{2} \\
\mathrm{C}_{18} \mathrm{H}_{36} \mathrm{O}_{2} \\
\mathrm{C}_{21} \mathrm{H}_{40} \mathrm{O}_{4}\left(\mathrm{C}_{3} \mathrm{H}_{6} \mathrm{O}_{2}+\mathrm{C}_{18} \mathrm{H}_{34} \mathrm{O}_{2}\right) \\
\mathrm{C}_{21} \mathrm{H}_{42} \mathrm{O}_{4}\left(\mathrm{C}_{3} \mathrm{H}_{6} \mathrm{O}_{2}+\mathrm{C}_{18} \mathrm{H}_{36} \mathrm{O}_{2}\right) \\
\mathrm{C}_{24} \mathrm{H}_{45} \mathrm{O}_{8} \mathrm{P} \\
\mathrm{C}_{24} \mathrm{H}_{47} \mathrm{O}_{8} \mathrm{P}\end{array}$ \\
\hline
\end{tabular}


Table 7. Molecular species of phosphatidic acid (PA) from Madhuca ellitica seeds.

\begin{tabular}{|c|c|c|c|c|c|c|c|}
\hline \multirow{2}{*}{ No. } & \multirow{2}{*}{ Molecular Species } & \multirow{2}{*}{$\begin{array}{c}\text { ESI-MS } \\
{[\mathrm{M}-\mathrm{H}]^{-} \mathbf{m} / \mathbf{z}}\end{array}$} & \multicolumn{2}{|c|}{ Monoisotopic Molecular Mass } & \multirow{2}{*}{ Molecular Formula } & \multicolumn{2}{|c|}{$\mathrm{MS}^{2}$} \\
\hline & & & Measured & Calculated & & $\begin{array}{l}\text { Fragment ion } \\
{[\mathrm{M}-\mathrm{H}-\mathrm{X}]^{-} \mathrm{m} / \mathrm{z}}\end{array}$ & $x$ \\
\hline 1 & 16:0/18:2 PA & 671.4643 & 672.4716 & 672.4730 & $\mathrm{C}_{37} \mathrm{H}_{69} \mathrm{O}_{8} \mathrm{P}$ & $\begin{array}{l}409.2375 \\
391.2271 \\
279.2274 \\
255.2313\end{array}$ & $\begin{array}{c}\mathrm{C}_{18} \mathrm{H}_{30} \mathrm{O} \\
\mathrm{C}_{18} \mathrm{H}_{32} \mathrm{O}_{2} \\
\mathrm{C}_{19} \mathrm{H}_{37} \mathrm{O}_{6} \mathrm{P} \\
\mathrm{C}_{21} \mathrm{H}_{37} \mathrm{O}_{6} \mathrm{P}\end{array}$ \\
\hline 2 & 16:0/18:1 PA & 673.4798 & 674.4871 & 674.4887 & $\mathrm{C}_{37} \mathrm{H}_{71} \mathrm{O}_{8} \mathrm{P}$ & $\begin{array}{l}417.2394 \\
409.2332 \\
391.2242 \\
281.2469 \\
255.2318\end{array}$ & $\begin{array}{c}\mathrm{C}_{16} \mathrm{H}_{32} \mathrm{O}_{2} \\
\mathrm{C}_{18} \mathrm{H}_{32} \mathrm{O} \\
\mathrm{C}_{18} \mathrm{H}_{34} \mathrm{O}_{2} \\
\mathrm{C}_{19} \mathrm{H}_{37} \mathrm{O}_{6} \mathrm{P} \\
\mathrm{C}_{21} \mathrm{H}_{39} \mathrm{O}_{6} \mathrm{P}\end{array}$ \\
\hline 3 & 18:2/18:2 PA & 695.4660 & 696.4727 & 696.4730 & $\mathrm{C}_{39} \mathrm{H}_{69} \mathrm{O}_{8} \mathrm{P}$ & $\begin{array}{l}433.2324 \\
415.2228 \\
279.2319\end{array}$ & $\begin{array}{c}\mathrm{C}_{18} \mathrm{H}_{30} \mathrm{O} \\
\mathrm{C}_{18} \mathrm{H}_{32} \mathrm{O}_{2} \\
\mathrm{C}_{21} \mathrm{H}_{37} \mathrm{O}_{6} \mathrm{P}\end{array}$ \\
\hline 4 & 18:1/18:2 PA & 697.4803 & 698.4876 & 698.4887 & $\mathrm{C}_{39} \mathrm{H}_{71} \mathrm{O}_{8} \mathrm{P}$ & $\begin{array}{l}435.2511 \\
433.2351 \\
417.2405 \\
415.2241 \\
281.2458 \\
279.2316\end{array}$ & $\begin{array}{c}\mathrm{C}_{18} \mathrm{H}_{30} \mathrm{O} \\
\mathrm{C}_{18} \mathrm{H}_{32} \mathrm{O} \\
\mathrm{C}_{18} \mathrm{H}_{32} \mathrm{O}_{2} \\
\mathrm{C}_{18} \mathrm{H}_{34} \mathrm{O}_{2} \\
\mathrm{C}_{21} \mathrm{H}_{37} \mathrm{O}_{6} \mathrm{P} \\
\mathrm{C}_{21} \mathrm{H}_{39} \mathrm{O}_{6} \mathrm{P}\end{array}$ \\
\hline 5 & $\begin{array}{c}\text { 18:0/18:2 PA 18:1/18:1 } \\
\text { PA }\end{array}$ & 699.4949 & 700.5022 & 700.5043 & $\mathrm{C}_{39} \mathrm{H}_{73} \mathrm{O}_{8} \mathrm{P}$ & $\begin{array}{c}437.2641 \\
435.2511 \\
419.256 \\
417.2382 \\
415.2223 \\
283.2608 \\
281.2479 \\
279.2322\end{array}$ & $\begin{array}{c}\mathrm{C}_{18} \mathrm{H}_{30} \mathrm{O} \\
\mathrm{C}_{18} \mathrm{H}_{32} \mathrm{O} \\
\mathrm{C}_{18} \mathrm{H}_{32} \mathrm{O}_{2} \\
\mathrm{C}_{18} \mathrm{H}_{34} \mathrm{O}_{2} \\
\mathrm{C}_{18} \mathrm{H}_{36} \mathrm{O}_{2} \\
\mathrm{C}_{21} \mathrm{H}_{37} \mathrm{O}_{6} \mathrm{P} \\
\mathrm{C}_{21} \mathrm{H}_{39} \mathrm{O}_{6} \mathrm{P} \\
\mathrm{C}_{21} \mathrm{H}_{41} \mathrm{O}_{6} \mathrm{P}\end{array}$ \\
\hline 6 & 18:0/18:1 PA & 701.5098 & 702.5171 & 702.5200 & $\mathrm{C}_{39} \mathrm{H}_{75} \mathrm{O}_{8} \mathrm{P}$ & $\begin{array}{c}437.2633 \\
435.2503 \\
419.2546 \\
417.2385 \\
283.2621 \\
281.247\end{array}$ & $\begin{array}{c}\mathrm{C}_{18} \mathrm{H}_{32} \mathrm{O} \\
\mathrm{C}_{18} \mathrm{H}_{34} \mathrm{O} \\
\mathrm{C}_{18} \mathrm{H}_{34} \mathrm{O}_{2} \\
\mathrm{C}_{18} \mathrm{H}_{36} \mathrm{O}_{2} \\
\mathrm{C}_{21} \mathrm{H}_{39} \mathrm{O}_{6} \mathrm{P} \\
\mathrm{C}_{21} \mathrm{H}_{41} \mathrm{O}_{6} \mathrm{P}\end{array}$ \\
\hline
\end{tabular}

* Precursor ion $\left[\mathrm{M}-\mathrm{H}^{-}\right.$. 


\subsection{Composition of the Molecular Species of the Phospholipids}

The percentages of the individual molecular species described above within each phospholipid class (PE, PC, PI, PG, and PA) are combined in Table 8. The composition of total phospholipids (Table 1) was used to determine the percentages of the individual molecular species within total phospholipids of M. ellitica seeds (Table 8). The weight content of each molecular species was calculated with regard to the content of phospholipids in total seed lipids $(44.5 \mathrm{~g} / \mathrm{kg})$. Five molecular species (16:0/18:1, 16:0/18:2, 18:1/18:1, 18:1/18:2, and 18:2/18:2) amounted about $91 \%$ of total PE. The major molecular species of PC were 16:0/18:1, 18:0/18:2, and 18:1/18:2. It was found that 16:0/18:1 was the main molecular species of both PI and PG.

Table 8. Content of molecular species of phospholipids obtained from Madhuca ellitica seeds.

\begin{tabular}{|c|c|c|c|c|}
\hline \multirow{2}{*}{$\begin{array}{l}\text { Phospholipid } \\
\text { Class }\end{array}$} & \multirow{2}{*}{ Molecular Species } & \multicolumn{3}{|c|}{ Concentration } \\
\hline & & $\begin{array}{c}\% \text { of Each } \\
\text { Phospholipid Class } \\
\end{array}$ & $\begin{array}{c}\text { \% of Total } \\
\text { Phospholipids }\end{array}$ & $\begin{array}{l}\mathrm{mg} / \mathrm{kg} \text { of Total } \\
\text { Lipids }\end{array}$ \\
\hline \multirow[t]{7}{*}{ PE } & 16:0/18:1 PE & 19.21 & 5.77 & 2567 \\
\hline & 16:0/18:2 PE & 16.13 & 4.85 & 2158 \\
\hline & 18:0/18:1 PE & 4.64 & 1.39 & 620 \\
\hline & 18:0/18:2 PE & 3.96 & 1.19 & 529 \\
\hline & 18:1/18:1 PE & 17.43 & 5.23 & 2329 \\
\hline & 18:1/18:2 PE & 27.18 & 8.16 & 3632 \\
\hline & 18:2/18:2 PE & 11.44 & 3.44 & 1529 \\
\hline \multirow[t]{7}{*}{ PC } & 16:0/18:0 PC & 3.96 & 1.19 & 530 \\
\hline & 16:0/18:1 PC & 30.11 & 9.05 & 4026 \\
\hline & 16:0/18:2 PC & 13.27 & 3.99 & 1774 \\
\hline & 18:0/18:2 PC & 17.10 & 5.14 & 2287 \\
\hline & 18:1/18:1 PC & 10.79 & 3.24 & 1443 \\
\hline & 18:1/18:2 PC & 19.78 & 5.94 & 2645 \\
\hline & 18:2/18:2 PC & 4.98 & 1.50 & 666 \\
\hline \multirow[t]{7}{*}{ PI } & 16:0/18:1 PI & 44.18 & 7.70 & 3427 \\
\hline & 16:0/18:2 PI & 1.01 & 0.18 & 78 \\
\hline & 16:1/18:1 PI & 20.92 & 3.65 & 1623 \\
\hline & 18:0/18:2 PI & 23.08 & 4.02 & 1790 \\
\hline & 18:1/18:1 PI & 5.25 & 0.92 & 407 \\
\hline & 18:2/18:2 PI & 2.02 & 0.35 & 157 \\
\hline & Other PI & 3.54 & 0.62 & 275 \\
\hline \multirow[t]{8}{*}{ PG } & 16:0/18:0 PG & 9.42 & 1.06 & 469 \\
\hline & 16:0/18:1 PG & 43.47 & 4.87 & 2167 \\
\hline & 16:0/18:2 PG & 22.05 & 2.47 & 1099 \\
\hline & 18:0/18:1 PG & 7.93 & 0.89 & 395 \\
\hline & 18:0/18:2 PG & 2.77 & 0.31 & 138 \\
\hline & 18:1/18:1 PG & 8.32 & 0.93 & 415 \\
\hline & 18:1/18:2 PG & 5.14 & 0.58 & 256 \\
\hline & Other PG & 0.90 & 0.10 & 45 \\
\hline \multirow[t]{7}{*}{ PA } & 16:0/18:1 PA & 29.01 & 1.91 & 852 \\
\hline & 16:0/18:2 PA & 15.98 & 1.05 & 469 \\
\hline & 18:0/18:1 PA & 7.05 & 0.47 & 207 \\
\hline & 18:0/18:2 PA & 4.74 & 0.31 & 139 \\
\hline & 18:1/18:1 PA & 18.19 & 1.20 & 534 \\
\hline & 18:1/18:2 PA & 19.62 & 1.29 & 576 \\
\hline & 18:2/18:2 PA & 5.41 & 0.36 & 159 \\
\hline
\end{tabular}

Results are given as the average of triplicate determinations. PE: phosphatidylethanolamine; PC: phosphatidylcholine; PI: phosphatidylinositol; PG: phosphatidylglycerol; PA: phosphatidic acid.

About 82\% of PA were comprised of four molecular species (16:0/18:1, 16:0/18:2, 18:1/18:1, and 18:1/18:2). Overall, three molecular species, namely 16:0/18:1 PC (9.05\%), 18:1/18:2 PE (8.16\%), and 16:0/18:1 PI (7.7\%), were mostly abundant in total phospholipids. Total phospholipids contained 32.05, $38.68,15.97$, and $5.65 \%$ of the unsaturated molecular species with one, two, three, and four double bonds in their acyl groups, respectively. The content of saturated molecular species was low $(2.25 \%$ of total phospholipids). Molecular species with 18:3 were not identified, probably, because of their low concentrations. 


\subsection{Sulfoquinovosyldiacylglycerol (SQDG)}

A pure SQDG fraction was isolated from polar lipids by preparative TLC and analyzed by HPLC-HRMS. Ten major signals of the negative quasi-molecular ions $[\mathrm{M}-\mathrm{H}]^{-}$.at $\mathrm{m} / \mathrm{z} 765.4858$, 793.5157, 815.4939, 817.5106, 819.5253, 839.4893, 841.5061, 843.5215, 845.5368, and 847.5527 were detected in the HRMS spectra of the SQDG fraction (Table 9). The elemental composition and the value of monoisotopic molecular mass confirmed the presence of SQDG in total lipids of M. ellitica seeds. The signals of carboxylate anions in $\mathrm{MS}^{2}$ spectra of the ions $[\mathrm{M}-\mathrm{H}]^{-}$of SQDG allowed us to identify fourteen molecular species which constituted about 99\% of total SQDG. There were 14:0/16:0, 16:0/16:0, 16:0/18:1, 16:0/18:2, 16:0/18:3, 16:1/18:1, 18:0/18:1, 18:0/18:2, 18:0/18:3, 18:1/18:1, 18:1/18:2, 18:1/18:3, 18:2/18:2, and 18:2/18:3 SQDG (Table 9).

The main molecular species was 16:0/18:1 SQDG (28.09\%), followed by 18:0/18:1 SQDG (17.97\%), and 16:0/18:2 SQDG (12.65\%). Unsaturated components predominated in the SQDG fraction, whereas the content of saturated molecular species was low (7.51\% of total SQDG). Several molecular species of SQDG contained one 18:3 acyl group, but a component with two 18:3 acyl groups was not found.

Table 9. Molecular species of sulfoquinovosyldiacylglycerol (SQDG) from Madhuca ellitica seeds.

\begin{tabular}{|c|c|c|c|c|c|c|c|c|}
\hline \multirow{2}{*}{ No. } & \multirow{2}{*}{$\begin{array}{l}\text { Molecular } \\
\text { Species }\end{array}$} & \multirow{2}{*}{$\begin{array}{l}\text { Content, } \\
\text { mol. } \%\end{array}$} & \multirow{2}{*}{ ESI-MS } & \multicolumn{2}{|c|}{$\begin{array}{c}\text { Monoisotopic } \\
\text { Molecular Mass }\end{array}$} & \multirow{2}{*}{$\begin{array}{l}\text { Molecular } \\
\text { Formula }\end{array}$} & \multicolumn{2}{|l|}{ MS $^{2}$} \\
\hline & & & & Measured & Calculated & & $\begin{array}{c}\text { Fragment Ion }^{a} \\
{[\mathrm{M}-\mathrm{H}-\mathrm{X}]^{-} \mathrm{m} / \mathrm{z}}\end{array}$ & $X$ \\
\hline 1 & 14:0/16:0 & 0.36 & 765.4858 & 766.4901 & 672.4730 & $\mathrm{C}_{39} \mathrm{H}_{74} \mathrm{O}_{12} \mathrm{~S}$ & $\begin{array}{l}537.2731 \\
509.2461\end{array}$ & $\begin{array}{l}\mathrm{C}_{14} \mathrm{H}_{28} \mathrm{O}_{2} \\
\mathrm{C}_{16} \mathrm{H}_{32} \mathrm{O}_{2}\end{array}$ \\
\hline 2 & $16: 0 / 16: 0$ & 7.15 & 793.5157 & 794.5198 & 794.5214 & $\mathrm{C}_{41} \mathrm{H}_{78} \mathrm{O}_{12} \mathrm{~S}$ & 537.2723 & $\mathrm{C}_{16} \mathrm{H}_{32} \mathrm{O}_{2}$ \\
\hline 3 & $16: 0 / 18: 3$ & 2.04 & 815.4939 & 816.5011 & 816.5057 & $\mathrm{C}_{43} \mathrm{H}_{76} \mathrm{O}_{12} \mathrm{~S}$ & 559.2593 & $\mathrm{C}_{16} \mathrm{H}_{32} \mathrm{O}_{2}$ \\
\hline 4 & $\begin{array}{l}16: 0 / 18: 2+ \\
16: 1 / 18: 1\end{array}$ & $\begin{array}{c}12.65 \\
4.72\end{array}$ & 817.5106 & 818.5179 & 818.5214 & $\mathrm{C}_{43} \mathrm{H}_{78} \mathrm{O}_{12} \mathrm{~S}$ & $\begin{array}{l}563.2875 \\
561.2734 \\
537.2730\end{array}$ & $\begin{array}{l}\mathrm{C}_{16} \mathrm{H}_{30} \mathrm{O}_{2} \\
\mathrm{C}_{16} \mathrm{H}_{32} \mathrm{O}_{2} \\
\mathrm{C}_{18} \mathrm{H}_{32} \mathrm{O}_{2}\end{array}$ \\
\hline 5 & $16: 0 / 18: 1$ & 28.09 & 819.5253 & 820.5325 & 820.537 & C43H80O12S & $\begin{array}{l}563.2892 \\
537.2747\end{array}$ & $\begin{array}{l}\mathrm{C}_{16} \mathrm{H}_{32} \mathrm{O}_{2} \\
\mathrm{C}_{18} \mathrm{H}_{34} \mathrm{O}_{2}\end{array}$ \\
\hline 6 & $18: 2 / 18: 3$ & 0.77 & 839.4893 & 840.4965 & 840.5057 & $\mathrm{C}_{45} \mathrm{H}_{76} \mathrm{O}_{12} \mathrm{~S}$ & $\begin{array}{l}561.2694 \\
559.2581\end{array}$ & $\begin{array}{l}\mathrm{C}_{18} \mathrm{H}_{30} \mathrm{O}_{2} \\
\mathrm{C}_{18} \mathrm{H}_{32} \mathrm{O}_{2}\end{array}$ \\
\hline 7 & $\begin{array}{c}18: 2 / 18: 2+ \\
18: 1 / 18: 3\end{array}$ & $\begin{array}{l}2.44 \\
0.75\end{array}$ & 841.5061 & 842.5134 & 842.5214 & $\mathrm{C}_{45} \mathrm{H}_{78} \mathrm{O}_{12} \mathrm{~S}$ & $\begin{array}{l}563.2841 \\
561.2733 \\
559.2638\end{array}$ & $\begin{array}{l}\mathrm{C}_{18} \mathrm{H}_{30} \mathrm{O}_{2} \\
\mathrm{C}_{18} \mathrm{H}_{32} \mathrm{O}_{2} \\
\mathrm{C}_{18} \mathrm{H}_{34} \mathrm{O}_{2}\end{array}$ \\
\hline 8 & $\begin{array}{c}18: 0 / 18: 3+ \\
18: 1 / 18: 2\end{array}$ & $\begin{array}{l}0.99 \\
5.76\end{array}$ & 843.5215 & 844.5287 & 844.537 & $\mathrm{C}_{45} \mathrm{H}_{80} \mathrm{O}_{12} \mathrm{~S}$ & $\begin{array}{l}565.3002 \\
563.2883 \\
561.2728 \\
559.2573\end{array}$ & $\begin{array}{l}\mathrm{C}_{18} \mathrm{H}_{30} \mathrm{O}_{2} \\
\mathrm{C}_{18} \mathrm{H}_{32} \mathrm{O}_{2} \\
\mathrm{C}_{18} \mathrm{H}_{34} \mathrm{O}_{2} \\
\mathrm{C}_{18} \mathrm{H}_{36} \mathrm{O}_{2}\end{array}$ \\
\hline 9 & $\begin{array}{c}18: 0 / 18: 2+ \\
18: 1 / 18: 1\end{array}$ & $\begin{array}{l}7.12 \\
8.75\end{array}$ & 845.5368 & 846.5441 & 846.5527 & $\mathrm{C}_{45} \mathrm{H}_{82} \mathrm{O}_{12} \mathrm{~S}$ & $\begin{array}{l}565.3005 \\
563.2894 \\
561.2738\end{array}$ & $\begin{array}{l}\mathrm{C}_{18} \mathrm{H}_{32} \mathrm{O}_{2} \\
\mathrm{C}_{18} \mathrm{H}_{34} \mathrm{O}_{2} \\
\mathrm{C}_{18} \mathrm{H}_{36} \mathrm{O}_{2}\end{array}$ \\
\hline 10 & 18:0/18:1 & 17.97 & 847.5527 & 848.5599 & 848.5683 & $\mathrm{C}_{45} \mathrm{H}_{84} \mathrm{O}_{12} \mathrm{~S}$ & $\begin{array}{l}565.3009 \\
563.2903\end{array}$ & $\begin{array}{l}\mathrm{C}_{18} \mathrm{H}_{34} \mathrm{O}_{2} \\
\mathrm{C}_{18} \mathrm{H}_{36} \mathrm{O}_{2}\end{array}$ \\
\hline
\end{tabular}

${ }^{\text {a }}$ Precursor ion $[\mathrm{M}-\mathrm{H}]^{-}$.

\section{Discussion}

The seeds of Madhuca are the base of numerous food products including a variety of lipid substances. Some of which are commonly referred to as "fat", "oil" or "butter" [13]. Technologies of their manufacturing are adopted to obtain the substances with target properties. Different methods are used for lipid analysis of these seed products and fresh seeds. Therefore, the comparable information on the lipid composition of $M$. ellitica seeds is limited.

The seeds of $M$. ellitica were found to be rich in lipids. The seed contains a considerable amount of crude non-polar compounds (up to $61 \%$ of $\mathrm{dw}$ ), which can be extracted by organic solvents. However, the lipid percentage does not seem to exceed $50 \%$ and depends on the extraction method $[10,11,13]$.

Classic Folch's method yielded 34\% of total lipids from fresh seeds and indicated that the lipid contents in M. ellitica seeds and other oilseed crops are similar [23]. Quality and utility of seed oils are mainly determined by their FA composition. The previous studies of the FA composition of total lipids 
have shown that 16:0 (11.7-25.9\%), 18:0 (19.1-32.2\%), 18:1n-9 (32.9-48.6\%), and 18:2n -6 (9.4-15.4\%) were the major FAs found in Indian M. longifolia seeds $[8,13,21]$.

The FAs of total lipids of our samples (Table 2) contained 18:0 at low content (11.5\%) and 18:1n-9 at high content (49.5\%). The oils with the high content of 18:1n-9 and the very low level of 18:3n-3 (0.1\%) are suitable for some cosmetic and pharmaceutical preparations. Some polyunsaturated FAs (PUFAs), such as 20:5n-3 and 22:6n-3, were earlier detected in mahua butter from the Indian buttercup [10] but were not found in the present study (Table 2). To our knowledge, these n-3 PUFAs are common for marine plants and animals. The enrichment of the polar lipid fraction with PUFAs was reported for animal lipids, but not for plant lipids (Table 2). The FA profiles of total, neutral, and polar lipids from M. ellitica seeds were quite similar (Table 2). Unusual FAs were not found in neutral lipids from M. ellitica seeds, in spite of the fact that seed TG often contain rare FAs [32]. The elevated content of 16:0 in the polar lipids (Table 2) has been previously observed in M. ellitica seeds [10]. In total lipids (TL) of oil seeds, the level of neutral lipids is highest, followed by glycolipids (GL) and phospholipids (PL). Neutral lipid classes, first of all, triacylglycerols (TG), prevailed in TL from M. ellitica seeds (Table 1). Extraction with hexane produced TL containing 91.2 and $0.2 \%$ of TG and PL, respectively [10]. The use of Folch's method [23] showed that M. ellitica seed TL contained 4.5\% of PL (Table 1). According to Ramadan and others (2006), the predominant PL subclasses were PE (57.7\%) followed by PC (30.6\%), while PI and PS were isolated in smaller quantities [10]. Our results confirmed that PE, PC and PI were the major PL subclasses, while PG was detected instead of PS. Additionally, PA was observed in the lipids of $M$. ellitica seeds. It is undoubted that the lipids of $M$. elliptica contained PG because its' chemical structures were confirmed by mass-spectrometry (Table 6). Generally, both PG and PS are known to be in seed lipids [19]. The discrepancy in PL class composition of M. ellitica may be explained by different extraction methods applied for TL preparation.

Phospholipids (PL) are recognized to play multiple roles in cell processes. PL form a bilayer of cell membranes and, therefore, are involved in important functions of the cell, such as energy transduction, signal transduction, trans-membrane transport and cell-cell recognition. The wide range of these biochemical processes explains the need for high diversity in phospholipid structure [36]. At the same time, only a few molecular species within each PL class demonstrate high biological activities. A potential pharmaceutical importance of an individual molecular species mainly depends on the chemical structure of its acyl groups [37-39]. Thus, common chemical characteristics, such as lipid class composition and total FA composition of each lipid class, are not enough for the detailed description of polar components of seed lipids. A lipidomic study of lipid molecular species is necessary for the use of these seeds effectively [40].

Fast determination of the profile of lipid molecular species became available as a result of the development of chromatography-mass-spectrometry [41-43]. The amounts of neutral lipids in seed oils are known to be the highest, followed by glycolipids and phospholipids [44]. Correspondingly, analysis of molecular species of neutral lipids and glycolipids are performed on a regular basis [19,45], but data on PL molecular species are scanty [46]. For M. ellitica seeds, molecular species profiles of TG of different fat products were earlier described [21], but data on PL molecular species were absent. In the present study, the chemical structure and the content of PL molecular species of M. ellitica seeds were determined for the first time by a high-resolution tandem mass-spectrometry. This MS method allows both the detection of lipid molecular species in a presence of other low-molecular weight compounds and the determination of acyl group chemical structures of each lipid molecular species [22]. Thirty-four molecular species belonging to five PL classes were identified (Table 3). It is likely that using the molecular species profile as a description of the PL class may be preferable to using the FA profile. Indeed, total FAs of PL contained 58.3\% of unsaturated FAs (Table 2), while unsaturated PL molecular species amounted to $97.7 \%$ of total PL (Table 3). In animal PL, polyunsaturated components are concentrated in position sn-2 with saturated FAs most abundant in position sn-1. In plants, the differences between the two positions are relatively minor. We did not determine the positional distributions of FAs in PL from the seeds of M. longifolia, but we showed 
that half of the molecular species contain two unsaturated acyl groups (Table 8). This distribution is explained by some differences between lipid metabolism in plants and other organisms [43]. The results will be important to determine nutraceutical and economical utility of $M$. ellitica seeds. Similar to PL, a charged group presents in molecules of sulfoquinovosyldiacylglycerol (SQDG), which is one of the important glycolipid (GL) classes in plants [47]. Membranes of chloroplasts and other plastids are enriched in GL. Thylakoid membranes of the chloroplasts are the site of the light reactions of photosynthesis. According to the important role of GL, these classes have been found in all seed oils. However, Kadri recently observed a lack of SQDG in polar lipids of Pinus halepensis seeds [19]. SQDG has been previously detected in the seeds of M. longifolia by Ramadan and others [10]. To confirm the presence and the structure of SQDG, this lipid class was obtained during the isolation of the polar lipid fraction from the seeds of M. ellitica. A profile of molecular species of SQDG was investigated similarly to that of PL. Among fourteen molecular species, three major species (16:0/18:1, 18:0/18:1, and 16:0/18:2) amounted to 58.7\% of total SQDG (Table 9). The molecular species of SQDG containing two unsaturated acyl groups (for example, 18:1/18:1, 18:1/18:2, 18:2/18:2, 18:2/18:3) were also found. The compositions of the SQDG molecular species have been described in different phyla, for example, a soil bacterium [48], cyanobacteria [49,50], microalgae, seaweeds [51], Arabidopsis leaves [45], and sea urchin [52]. These molecular species were characterized by the high degree of saturation of FAs and contained one or two saturated acyl groups. Antibacterial, antitumor, and antiviral activities were reported for SQDG. Since the biological activities depend on a FA saturation degree, we suppose that unsaturated molecular species of SQDG from the seeds of $M$. ellitica enhance the pharmacological potential of these compounds.

\section{Conclusions}

The seed oil from the buttercup tree M. ellitica is widely used in India and Indochina. However, a detailed analysis of its polar lipid fractions has not been performed. A lipidomic approach showed that the seeds of $M$. ellitica contain a variety of polar lipid compounds with both biotechnological potential and pharmaceutical interest. Our research enhances the industrial potential of M. ellitica and shows that their seeds may be a good source of polar lipids, which contain about $95 \%$ of unsaturated components. Further studies are needed to extend knowledge concerning the distribution of SQDG molecular species between oil seeds.

Author Contributions: Investigation, D.L.P., T.Q.T., L.P.T.D., A.B.I., T.D.T., B.M. and L.G.B.; Supervision, P.Q.L. and L.M.B.; Writing—original draft, D.L.P.

Funding: This research received no external funding

Conflicts of Interest: The authors declare no conflict of interest

\section{References}

1. Kundu, M. Madhuca longifolia (Koenig) J. F. Macb. Seed Leaflets 2012, 156.

2. Chopra, R.N.; Nayar, S.L.; Chopra, I.C. Glossary of Indian Medicinal Plant; National Institute of Science communication and Information resource (CSIR): New Delhi, India, 1985.

3. Benerji, D.S.N.; Rajini, K.; Rao, B.S. Studies on physico-chemical and nutritional parameter for the production of ethanol from Mahua flower (madhuca indica) using Saccharomyces cerevisiae-3090 through submerged fermentation (smf). J. Microb. Biochem. Technol. 2010, 2, 46-50. [CrossRef]

4. Siddiqui, S.B.; Khan, S.; Kardar, M.N. A New Isoflavone from the Madhuca latifolia. Nat. Prod. Res. 2010, 24, 76-80. [CrossRef]

5. Yoshikawa, K.; Tanaka, M.; Arihara, S.; Pal, B.C.; Roy, S.K.; Matsumura, E.; Katayama, S. New oleanene triterpenoid saponins from Madhuca longifolia. J. Nat. Prod. 2000, 63, 1679-1681. [CrossRef]

6. Yosioka, I.; Inada, A.; Kitagawa, I. Soil bacterial hydrolysis leading to genuine aglycon. VIII. Structures of a genuine sapogenol protobassic acid and a prosapogenol of seed kernels of Madhuca longifoli. Tetrahedron 1974, 30, 707-714. [CrossRef] 
7. Siddiqui, S.B.; Khan, S.; Kardar, M.N.; Aslam, H. Chemical constituents from the fruits of Madhuca latifolia. Helventica Chim. Acta. 2004, 87, 1194-1201. [CrossRef]

8. Ruckmini, C. Reproductive toxicology and nutritional studies on mahua oil (Madhuca latifolia). Food Chem. Toxicol. 1990, 28, 601-605. [CrossRef]

9. Manorama, R.; Chinnasamy, N.; Rukmini, C. Multigeneration studies on red palm oil, and on hydrogenated vegetable oil containing mahua oil. Food Chem. Toxicol. 1993, 31, 369-375. [CrossRef]

10. Ramadan, M.F.; Sharanabasappa, G.; Parmjyothi, S.; Seshagiri, M.; Moersel, J.T. Profile and levels of fatty acids and bioactive constituents in mahua butter from fruit-seeds of buttercup tree [Madhuca longifolia (Koenig)]. Eur. Food Res. Technol. 2006, 222, 710-718. [CrossRef]

11. Singh, A.; Singh, I.S. Chemical evaluation of Mahua (Madhuca indica) seed. Food Chem. 1991, 40, $221-228$. [CrossRef]

12. Ayyanar, M.; Ignacimuthu, S. Traditional knowledge of kani tribals in Kouthalai of Tirunelveli hills, Tamil Nadu. India. J. Ethnopharmacol. 2005, 102, 246-255. [CrossRef]

13. Yadav, S.; Suneja, P.; Hussain, Z.; Abraham, Z.; Mishra, S.K. Prospects and potential of Madhuca longifolia (Koenig) J.F. Macbride for nutritional and industrial purpose. Biomass Bioenergy 2011, 35, 1539-1544. [CrossRef]

14. Parrota, J.A. Healing Plants of Peninsular India; CABI Publishing: London, UK, 2001.

15. Gunstone, F.D. Phospholipid Technology and Applications; The Oily Press: Bridgwater, UK, 2008.

16. Schwudke, D.; Schuhmann, K.; Herzog, R.; Bornstein, S.R.; Shevchenko, A. Shotgun lipidomics on high resolution mass spectrometers. Cold Spring Harb. Perspect. Biol. 2001, 3, a004614. [CrossRef]

17. Frega, N.G.; Pacetti, D.; Boselli, E. Characterization of phospholipid molecular species by means of HPLC-tandem mass spectrometry. In Tandem Mass Spectrometry-Applications and Principles; Prasain, J., Ed.; InTech: London, UK, 2012; pp. 637-672.

18. Gray, C.G.; Lasiter, A.D.; Li, C.; Leblond, J.D. Mono- and digalactosyldiacylglycerol composition of dinoflagellates. I. Peridinin-containing taxa. Eur. J. Phycol. 2009, 44, 191-197. [CrossRef]

19. Kadri, N.; Khettal, B.; Yahiaoui-Zaidi, R.; Barragan-Montero, V.; Montero, J.L. Analysis of polar lipid fraction of Pinus halepensis Mill. seeds from North Algeria. Ind. Crops Prod. 2013, 51, 116-122. [CrossRef]

20. Dodson, V.J.; Mouget, J.L.; Dahmen, J.L.; Leblond, J.D. The long and short of it: Temperature dependent modifications of fatty acid chain length and unsaturation in the galactolipid profiles of the diatoms Haslea ostrearia and Phaeodactylum tricornutum. Hydrobiologia 2014, 727, 95-107. [CrossRef]

21. Marikkar, J.M.N.; Ghazali, H.M.; Long, K. Composition and thermal characteristics of Madhuca longifolia seed fat and its solid and liquid fractions. J. Oleo Sci. 2010, 59, 7-14. [CrossRef]

22. Peterson, B.L.; Cummings, B.S. A review of chromatographic methods for the assessment of phospholipids in biological samples. Biomed. Chromatogr. 2006, 20, 227-243. [CrossRef]

23. Imbs, A.B.; Dang, L.P.; Rybin, V.G.; Nguyen, N.T.; Pham, L.Q. Distribution of very-long-chain fatty acids between molecular species of different phospholipid classes of two soft corals. Biochem. Anal. Biochem. 2015, $4,1-3$.

24. Carter, J.D.; Leblond, J.D. Red (hot) algae: Modulation of mono-and digalactosyldiacylglycerol-associated fatty acids of Polysiphonia sp. and Porphyridium sp. in response to growth temperature. Eur. J. Phycol. 2018, 53, 460-470. [CrossRef]

25. Honda, M.; Ishimaru, T.; Itabashi, Y.; Vyssotski, M. Glycerolipid composition of the red macroalga Agarophyton Chilensis and comparison to the closely related Agarophyton vermiculophyllum producing different types of eicosanoids. Mar. Drugs 2019, 17, 96. [CrossRef] [PubMed]

26. Folch, J.F.; Lees, M.; Sloane Stanley, G.H. A simple method for the isolation and purification of total lipids from animal tissue. J. Biol. Chem. 1957, 226, 497-509. [PubMed]

27. Hamoutene, D.; Puestow, T.; Miller-Banoub, J.; Wareham, V. Main lipid classes in some species of deep-sea corals in the Newfoundland and Labrador region (Northwest Atlantic Ocean). Coral Reefs 2008, 27, 237-246. [CrossRef]

28. Khotimchenko, S.V.; Kulikova, I.V. Lipids of different parts of the lamina of Laminaria japonica Aresch. Bot. Mar. 2000, 43, 87-91. [CrossRef]

29. Vaskovsky, V.E.; Kostetsky, E.Y.; Vasendin, I.M. A universal reagent for phospholipids analysis. J. Chromatogr. 1974, 114, 129-141. [CrossRef]

30. Svetashev, V.I. Mild method for preparation of 4,4-dimethyloxazoline derivatives of polyunsaturated fatty acids for GC-MS. Lipids. 2011, 46, 463-467. [CrossRef] [PubMed] 
31. Stransky, K.; Jursik, T.; Vitek, A. Standard equivalent chain length values of monoenic and polyenic (methylene interrupted) fatty acids. J. High Resolut. Chromatogr. 1997, 20, 143-158. [CrossRef]

32. The AOCS Lipid Library-Mass Spectrometry of Fatty Acid Derivatives. Available online: http://lipidlibrary. aocs.org/ms/masspec.html (accessed on 16 August 2014).

33. Postle, A.D.; Wilton, D.C.; Hunt, A.N.; Attard, G.S. Probing phospholipid dynamics by electrospray ionisation mass spectrometry. Prog. Lipid Res. 2007, 46, 200-224. [CrossRef]

34. Imbs, A.B.; Dang, L.P.T.; Rybin, V.G.; Svetashev, V.I. Fatty acid, lipid class, and phospholipid molecular species composition of the soft coral Xenia sp. (Nha Trang Bay, the South China Sea, Vietnam). Lipids 2015, 60, 575-589. [CrossRef]

35. Mohamed, A.; Bhardwaj, H.; Hamama, A.; Webber, C.L., III. Chemical composition of kenaf (Hibiscus cannabinus L.) seed oil. Ind. Corp. Prod. 1995, 4, 157-165. [CrossRef]

36. Dowhan, W. Molecular basis for membrane phospholipid diversity: Why are there so many lipids? Annu. Rev. Biochem. 1997, 66, 199-232. [CrossRef] [PubMed]

37. Postle, A.D. Phospholipid lipidomics in health and disease. Eur. J. Lipid Sci. Tech. 2009, 111, 2-13. [CrossRef]

38. Hermansson, M.; Hokynar, K.; Somerharju, P. Mechanisms of glycerophospholipid homeostasis in mammalian cells. Prog. Lipid Res. 2011, 50, 240-257. [CrossRef]

39. Astudillo, A.M.; Balgoma, D.; Balboa, M.A.; Balsinde, J. Dynamics of arachidonic acid mobilization by inflammatory cells. Biochim. Biophys. Acta 2012, 1821, 249-256. [CrossRef] [PubMed]

40. Pacetti, D.; Boselli, E.; Lucci, P.; Frega, N.G. Simultaneous analysis of glycolipids and phospholids molecular species in avocado (Persea americana Mill.) fruit. J. Chromatogr. A 2007, 1150, 241-251. [CrossRef] [PubMed]

41. Postle, A.D. Lipidomics. Curr. Opin. Clin. Nut. Metab. Care. 2012, 15, 127-133. [CrossRef]

42. Brouwers, J.F. Liquid chromatographic-mass spectrometric analysis of phospholipids. Chromatography, ionization and quantification. Biochim. Biophys. Acta 2011, 1811, 763-775. [CrossRef] [PubMed]

43. Vu, H.S.; Shiva, S.; Roth, M.R.; Tamura, P.; Zheng, L.Q.; Sarowar, S.; Li, M.; Honey, S.; McEllhiney, D.; Hinkes, P.; et al. Lipid changes after leaf wounding in Arabidopsis thaliana: Expanded lipidomic data form the basis for lipid co-occurrence analysis. Plant J. 2014, 80, 728-743. [CrossRef] [PubMed]

44. Schmid, K.M.; Ohlrogge, J.B. Lipid metabolism in plants. In New Comprehensive Biochemistry, Biochemistry of Lipids, Lipoproteins and Membranes, 4th ed.; Vance, D.E., Vance, J.E., Eds.; Elsevier: New York, NY, USA, 2002; Volume 36, pp. 93-126.

45. Frentzen, M. Phosphatidylglycerol and sulfoquinovosyldiacylglycerol: Anionic membrane lipids and phosphate regulation. Curr. Opin. Plant. Biol. 2004, 7, 270-276. [CrossRef]

46. Basconcillo, L.S.; Zaheer, R.; Finan, T.M.; McCarry, B.E. A shotgun lipidomics approach in Sinorhizobium meliloti as a tool in functional genomics. J. Lipid. Res. 2009, 50, 1120-1132. [CrossRef]

47. Kim, Y.H.; Yoo, J.S.; Kim, M.S. Structural characterization of sulfoquinovosyl, monogalactosyl and digalactosyl diacylglycerols by FAB-CID-MS/MS. J. Mass Spect. 1997, 32, 968-977. [CrossRef]

48. Xue, C.H.; Hu, Y.Q.; Saito, H.; Zhang, Z.H.; Li, Z.J.; Cai, Y.P.; Ou, C.R.; Lin, H.; Imbs, A.B. Molecular species composition of glycolipids from Sprirulina platensis. Food Chem. 2002, 77, 9-13. [CrossRef]

49. Li, H.Y.; Yan, X.J.; Xu, J.L.; Zhou, C.X. Precise identification of photosynthetic glycerolipids in microalga Tetraselmis chuii by UPLC-ESI-Q-TOF-MS. Sci. China. 2008, 51, 1101-1107. [CrossRef]

50. Plouguerné, E.; da Gama, B.A.P.; Pereira, R.C.; Barreto-Bergter, E. Glycolipids from seaweeds and their potential biotechnological applications. Front. Cell Infect. Microbiol. 2014, 4, 174. [CrossRef] [PubMed]

51. Melo, T.; Alves, E.; Azevedo, V.; Martins, A.S.; Neves, B.; Domingues, P.; Calado, R.; Abreu, M.H.; Domingues, M.R. Lipidomics as a new approach for the bioprospecting of marine macroalgae-Unraveling the polar lipid and fatty acid composition of Chondrus crispus. Algal Res. 2015, 8, 181-191. [CrossRef]

52. Logvinov, S.V.; Denisenko, V.A.; Dmitrenok, P.S.; Moiseenko, O.P. Sulfoquinovosyldiacylglycerines from Scaphechinus mirabilis. Chem. Nat. Comp. 2012, 48, 175-179. [CrossRef]

(C) 2019 by the authors. Licensee MDPI, Basel, Switzerland. This article is an open access article distributed under the terms and conditions of the Creative Commons Attribution (CC BY) license (http://creativecommons.org/licenses/by/4.0/). 